$1-1-2016$

\title{
Worlds Colliding: Competition Policy and Bankruptcy Asset Sales
}

Max Huffman

Follow this and additional works at: https://digitalcommons.law.villanova.edu/vlr

Part of the Bankruptcy Law Commons

\section{Recommended Citation}

Max Huffman, Worlds Colliding: Competition Policy and Bankruptcy Asset Sales, 60 Vill. L. Rev. 839 (2016).

Available at: https://digitalcommons.law.villanova.edu/vlr/vol60/iss5/1

This Article is brought to you for free and open access by Villanova University Charles Widger School of Law Digital Repository. It has been accepted for inclusion in Villanova Law Review by an authorized editor of Villanova University Charles Widger School of Law Digital Repository. 


\title{
VILLANOVA LAW REVIEW
}

Volume 60

NUMBer 5

\section{Articles}

\section{WORLDS COLLIDING: COMPETITION POLICY AND BANKRUPTCY ASSET SALES}

\author{
Max HuffMan*
}

\section{INTRODUCTION}

$\mathrm{W}$ ORK on the effects of mergers and acquisitions conducted in bankruptcy on bankruptcy law and policy limits its ambition to the bankruptcy goals of maximizing estate value and protecting the rights of stakeholders, remaining naive as to the larger question of the role of bankruptcy in the broader economic regulatory framework for depressed industries. $^{1}$ Existing scholarship reflects a debate pitting theoretical arguments $^{2}$ against empirical studies ${ }^{3}$ on the question of whether bankruptcy mergers and acquisitions, in particular those conducted as fire sales outside of the plan-confirmation process, adequately protect the rights of all the bankruptcy estate's constituents. ${ }^{4}$

* Professor of Law, Indiana University Robert H. McKinney School of Law. Thanks to Mark Anderson, Dan Cole, Susan deMaine, Roy Englert, Park Erkmann, Bert Foer, Nicholas Georgakopoulos, Ken Heyer, Dennis Johnson, Rob Katz, Lynn LoPucki, Danny Sokol, Bill Stallings, Michael Van Alstine, Spencer Waller, George Wright, and Josh Wright, as well as participants in colloquia at the University of Maryland, the University of Toledo, Case Western University, and Indiana University-McKinney, for conversations on this topic or comments on drafts. John Holley and Sam Kerkhoff, IU-McKinney Class of 2013, provided excellent research assistance.

1. A few examples exist of articles discussing conflicts between bankruptcy and other regulatory schemes. See, e.g., Josef S. Athanas \& Peter P. Knight, Resolving Conflicts Between the Bankruptcy Code and Other Federal and State Laws, 11 J. Bankr. L. \& PRAC. 237, 238-47 (2002) (examining preemption doctrines involving environmental law, labor law, criminal law, and state foreclosure law).

2. E.g., Douglas G. Baird \& Robert K. Rasmussen, The End of Bankruptcy, 55 Stan. L. Rev. 751 (2002).

3. E.g., Lynn M. LoPucki \& Joseph W. Doherty, Bankruptcy Fire Sales, 106 МicH. L. Rev. 1 (2007).

4. See Anne M. Anderson \& Yung-Yu Ma, Acquisitions in Bankruptcy: 363 Sales Versus Plan Sales and the Existence of Fire Sales, 22 Am. Bankr. Inst. L. Rev. 1 (2014) (describing debate); Melissa B. Jacoby \& Edward J. Janger, Ice Cube Bonds: Allocating the Price of Process in Chapter 11 Bankruptcy, 123 Yale L.J. 862 (2014) (same). 
This Article is the first to fully examine the procedural and substantive conflicts between bankruptcy and antitrust in the context of bankruptcy fire sales. Those conflicts arise because bankruptcy and antitrust have opposing goals. ${ }^{5}$ Neither scholars nor courts have resolved the conflict between bankruptcy and antitrust despite the increasing frequency of potentially anticompetitive mergers and acquisitions ${ }^{6}$ in bankruptcy. The rule from Butner $v$. United States-the Butner principle ${ }^{7}$ - speaks to uniformity of results in and out of bankruptcy for constituents of the bankruptcy estate, but no analogous doctrine addresses the need for uniform treatment of non-bankruptcy policies that arise in the context of a business bankruptcy proceeding. I address that gap for non-constituents with antitrust concerns flowing from a reorganization.

Antitrust merger review and bankruptcy represent two different approaches to the same goal of optimizing the structure of an industry. Antitrust allows business combinations in which efficiencies from scale or synergy outweigh losses due to concentration, including through more complex remedies than the merely binary stop (injunction) or go (no injunction). Bankruptcy reorganization prevents losses in an industry by avoiding the idling of assets that have a going-concern premium. Antitrust law's "failing-firm" defense, allowing mergers that might otherwise be blocked in order to prevent the wasting of assets, is "bankruptcy-lite." The Bankruptcy Code excepts from the automatic stay actions "to enforce such governmental unit's ... police and regulatory power ...."8 Bankruptcy

5. James M. Spears, Federal Merger Enforcement in Bankruptcy, 6 Antitrust MAg., Spring 1992, at 19.

$[\mathrm{E}]$ ach regime is designed to accomplish very different objectives. Premerger review under Section 7A is designed to provide the Commission and the Department of Justice with an opportunity to identify, analyze and, where necessary, take steps to halt anticompetitive transactions prior to consummation. Proceedings under the Bankruptcy Code, whether arising as part of a general plan of liquidation under Chapter 7 or as part of Chapter 11 reorganization, are designed to benefit creditors or the reorganizing corporation by maximizing the return on any assets sold. The potential for friction between these two regimes arises because prospective purchasers are willing to pay a premium for assets that confer Id. market power.

6. Bankruptcy and antitrust employ different terms as a matter of both tradition and statute: "asset sales," "mergers," "acquisitions," "sales of property of the estate," "combinations," and others. I combine all such terms under the phrases "mergers and acquisitions" and-as a subset of that concept, "bankruptcy fire sales"- throughout this Article.

7. Butner v. United States, 440 U.S. 48, 55 (1979) ("Property interests are created and defined by state law. ... [T] [Tere is no reason why such interests should be analyzed differently simply because an interested party is involved in a bankruptcy proceeding."), superseded in part by statute, Bankruptcy Reform Act of 1994, Pub. L. No. 103-394, 108 Stat. 4106. See generally G. Marcus Cole \& Todd J. Zywicki, Anna Nicole Smith Goes Shopping: The New Forum-Shopping Problem in Bankruptcy, 2010 UtaH L. Rev. 511, 512-14, 521 (discussing Butner).

8. 11 U.S.C. $\$ 362$ (b) (4) (2012). 
courts are constrained by laws and regulations that apply outside of bankruptcy, including anti-merger laws, and are charged with interpreting and applying those laws.

Three core distinctions divide bankruptcy and antitrust in the context of mergers and acquisitions. First, bankruptcy is backward-looking and deals with upstream investor constituents who may be owners or creditors of the firm. Antitrust is forward-looking. It deals with downstream consumer constituents who are not present at the time challenged conduct occurs and lack a voice in that conduct. ${ }^{9}$ When a merger or acquisition takes place in bankruptcy, those constituencies conflict. Bankruptcy protects investors by maximizing the payout from the assets ${ }^{10}$ while antitrust, if applied, protects consumers by preserving marketplace competition.

Second, bankruptcy goals are served by a merger or acquisition that benefits the investors in the bankrupt firm by maximizing the estate value. Maximal value is likely to occur where the merger or acquisition creates market power for the acquiring firm that can be leveraged to the detriment of consumers. Antitrust law disfavors mergers or acquisitions producing market power unless there are countervailing efficiencies that outweigh the harms. ${ }^{11}$ The benefits bankruptcy seeks, in terms of maximum value to the investors in the firm, are likely to be realized in the circumstances in which antitrust harms from increased market power are greatest.

Third, as the term fire sales suggests, mergers and acquisitions in bankruptcy proceed at a much accelerated pace. Observers frequently speak of the "need for speed" or of concerns for a "melting ice cube." 12 Where antitrust review is protected in bankruptcy, the enforcement agencies are given a shorter period to analyze the transaction and to take steps to oppose it before the parties close. ${ }^{13}$ That same speed is anathema to meaningful antitrust review. Antitrust review of mergers and acquisitions is a fact- and economic-analysis-intensive process, frequently requiring review of millions of documents, retention of expert economic and industry consultants, and preparation of lengthy expert reports. Parties seeking to accomplish complex mergers and acquisitions grant the enforcement agencies extensions of time beyond the statutory review periods as a mat-

9. Most modern understandings of antitrust treat consumer welfare as the law's overarching goal. See Robert H. Bork, The Antitrust Paradox: A Policy at WAR with Itself (rev. ed. 1993). Because consumer transactions are in relevant regard instantaneous, a consumer's relationship with a firm either precedes or postdates conduct. It does not span the conduct.

10. See Thomas H. Jackson, The Logic and Limits of Bankruptcy Law (1986).

11. U.S. Dep't of Justice \& Fed. Trade Comm'n, Horizontal Merger GuideLINES (2010) [hereinafter 2010 GuIDELINES], http://www.justice.gov/sites/default/files/atr/legacy/2010/08/19/hmg-2010.pdf [http://perma.cc/V56YVQRR].

12. See Jacoby \& Janger, supra note 4 .

13. See 11 U.S.C. $\$ 363$ (b) (2) (B); 15 U.S.C. § 18a(f) (2012). 
ter of course. ${ }^{14}$ Meaningful antitrust review is not possible on the shorter calendar available in bankruptcy. These three effects combine to produce a likelihood of under-enforcement of antitrust laws relative to the optimum, with the danger that economic decline in an industry will produce an inefficient industry structure leading to broader economic harms.

The conflict I identify here is serious and enduring. It raises questions of the relative competencies of (1) the bankruptcy courts applying the Bankruptcy Code and (2) the federal antitrust enforcement agencies enforcing the anti-merger laws to produce an efficient allocation of a failing business's assets. In this Article, I propose approaches to reconcile this conflict that are workable within the parameters of the existing bankruptcy scheme. Because bankruptcy proceedings undermine full antitrust review of business combinations, the approach recommended here will correct the imbalance. The freedom to conduct bankruptcy asset sales will be somewhat lessened while the countervailing opportunity to ensure the maintenance of competitive markets will be enhanced.

Part II gives the background of the existing substantive law and procedural mechanisms for analyzing business combinations under the antitrust and bankruptcy laws and procedures. Part II analyzes antitrust merger control under Clayton Act Section 7, the leading anti-merger provision in the federal antitrust laws, including premerger notification and the failingfirm defense to a merger challenge. This Part also describes the parallel world of business combinations under the Bankruptcy Code. Finally, Part II discusses Bankruptcy Code Section 363(b), which provides for the sale of assets "other than in the ordinary course of business," 15 as well as mergers conducted as part of the plan of reorganization under Code Section $1123 .{ }^{16}$

Part III identifies the fundamental conflict between the goals of bankruptcy law and procedure on one hand and those of antitrust merger review on the other. That conflict's existence suggests business combinations under Section 363(b) should produce greater value for the bankruptcy estate than do those conducted as plan sales. This Part continues to discuss empirical work that demonstrates the contrary reality that values realized in 363(b) sales lag those realized in plan sales. I offer a theoretical explanation for this surprising result and show that the harm from systemic over-reliance on 363(b) sales is greater than either a pure bankruptcy analysis or a pure antitrust analysis might suggest.

In Parts IV and V, I discuss the optimal reconciliation of this conflict and offer solutions. Part IV shows that where a conflict arises between diffuse constituents of the bankruptcy estate and diffuse consumer inter-

14. ABA, The Merger Review Process: A Step-by-Step Guide to U.S. ANd Foreign Merger Review (Ilene K. Gotts, ed., 3d ed. 2006) [hereinafter Merger Review Process].

15. 11 U.S.C. $\$ 363(\mathrm{~b})$.

16. 11 U.S.C. $\$ 1123(\mathrm{a})(5)$. 
ests, consumers-who lack the ability to bargain ex ante-should prevail. From that demonstration, I conclude that ties should break in favor of merger enforcement policy rather than the policies of bankruptcy reorganization. Part $\mathrm{V}$ discusses several practical possibilities to bring about this result, relying primarily on hypothetical amendments to the Bankruptcy Code, but also suggests opportunities for change in the Code's interpretation brought about through the common-law process.

\section{Antitrust Review of Business Combinations and Bankruptcy Treatment of Antitrust Concerns}

\section{A. Antitrust Merger Control Under Clayton Act Section 7}

The federal antitrust laws prohibit a business combination "the effect of such acquisition [which] may be substantially to lessen competition, or to tend to create a monopoly." 17 This anti-merger prohibition operates to preserve marketplace competition by blocking mergers that threaten undue concentration. Merger enforcement is placed in the hands of both federal and state government antitrust enforcers as well as private plaintiffs. For transactions above a certain size, premerger notice is required to the Federal Trade Commission (FTC) under the Hart-Scott-Rodino Act, which enables the FTC or the Department of Justice to investigate and sometimes to seek injunctive relief before the merger is consummated. ${ }^{18}$

Private plaintiff enforcement is less common in merger litigation than it is in other areas of antitrust enforcement, although private rights of action do exist and private plaintiffs do become involved in merger challenges. ${ }^{19}$ The purpose of private plaintiff enforcement in the scheme is a subject of some debate among commentators. The best explanation holds that private plaintiffs serve as a backstop when federal enforcement fails to sufficiently prevent or remedy anticompetitive business combinations. ${ }^{20}$

The Clayton Act condemns purchases of assets or equity shares, "the effect of [which] [ ] may . . tend to create a monopoly."21 The statute regulates corporate mergers as well as acquisitions. A business combina-

17. Clayton Act, 15 U.S.C. $§ 18$. Since 1950 , the prohibition has applied to both stock purchases and asset purchases.

18. Id. at $\S 18$ a.

19. For one recent example, Sprint pursued litigation parallel to the Department of Justice's successful effort to block the merger between AT\&T and TMobile.

20. A recent example of private-plaintiff enforcement is the temporary restraining order sought in the fall of 2013 by a consumer class challenging the American Airlines and U.S. Airways merger brought in bankruptcy court after the settlement between the Justice Department and the merging airlines. Supporting the backstop theory of private enforcement, lead counsel Joseph Alioto reportedly criticized the Department of Justice for the settlement agreement. See Nicholas Sakelaris, American, US Airways Meet on Private Antitrust Suit, Dallas Bus. J. (Nov. 20, 2013), http://www.bizjournals.com/dallas/news/2013/11/20/american-us-airways-meet-wednesday.html [http://perma.cc/PAB2-QTVY].

21. 15 U.S.C. $\$ 18$. 
tion will implicate the prohibition if, by increasing concentration, it creates opportunity and incentive for the merged firm to raise prices unilaterally or in coordination with its competitors. ${ }^{22}$ Modern interpretations of the Clayton Act recognize that harms from concentration can be mitigated if the merger increases efficiency through scale economies or productive synergies. ${ }^{23}$

\section{B. The Failing-Firm Defense}

Federal antitrust policy recognizes problems of industrial decline and poor management leading to consolidation and changes of ownership. ${ }^{24}$ The failing firm defense, recognized as a matter of case law, legislative history, and enforcement guidelines, operates as a sort of "bankruptcy-lite" to allow mergers to proceed where the alternative is the dissipation of productive assets. ${ }^{25}$ The failing-firm defense to a merger challenge has been

22. See 2010 Guidelines, supra note 11 , at 2 .

23. Id. at 25; FTC v. H.J. Heinz Co., 246 F.3d 708 (D.C. Cir. 2001); FTC v. Staples, Inc., 970 F. Supp. 1066 (D.D.C. 1997). Federal anti-merger regulation is mature. Since 1968, the Department of Justice and FTC have collaborated on guidelines for horizontal merger enforcement that describe the agencies' intended exercise of their prosecutorial discretion in merger enforcement. See 2010 Guidelines, supra note 11. First promulgated in 1968 and reissued most recently in 2010, the modern Horizontal Merger Guidelines reflect many decades of refinement in economic and legal thought.

The 2010 version was drafted over two years with input by policy-makers, academics, and members of the regulated communities. The 2010 Guidelines are broadly recognized as an authoritative statement of the law governing mergers between horizontal competitors. See generally Hillary Greene, Guideline Institutionalization: The Role of Merger Guidelines in Antitrust Discourse, 48 WM. \& MARY L. Rev. 771, 776 (2006) ("The influence of this guideline system emerges from a process of institutionalization through which the guidelines become valued for more than the persuasive power of their ideas. This institutionalization process arguably has had an undue influence on the common law as courts have failed to fully engage the legal and economic substance of the guidelines.").

24. See generally Ashley J. Austin, Comment, Food for Thought: The Efficiencies Achieved by Trimming an Industry at Overcapacity Through Mergers vs. Chapter 11 Reorganizations, 25 Emory Bankr. Dev. J. 147, 152-72 (2008) (discussing origin and development of failing-firm defense).

25. Commentators disagree regarding whether the failing-firm defense is economically efficient. A critic might argue that the result of approving an otherwise illegal merger always or nearly always leads to an inefficient outcome. According to this argument, the efficient outcome is the result obtained under antitrust review in the absence of the defense, and any other result must be less efficient. A proponent of the defense might argue that its application often leads to an efficient outcome, or is at least not inefficient.

Professor Campbell makes a case for the defense's efficiency by observing that a failing company has two choices: to exit the market or to sell out to another firm in its present market. Thomas J. Campbell, The Efficiency of the Failing Company Defense, 63 Tex. L. Rev. 251, 257 (1984). Campbell notes that critics of the defense

have not considered the other side of the balance-the consequences of letting a firm simply leave the industry. When a failing firm departs from the market, the resources it had employed are devoted to their next best use, which could be either scrap or the manufacture of a completely different product. This causes an economic loss because the resources have 
recognized in federal case law since at least $1930 .{ }^{26}$ Congress declined to disturb it when amending the anti-merger statute, Clayton Act Section 7, in 1950. The Antitrust Division and Federal Trade Commission have memorialized it in every version of the Horizontal Merger Guidelines since their inception in 1968. And academic commentators nearly universally recognize the defense's validity.

The failing-firm defense is the antitrust law's scheme for corporate reorganization. ${ }^{27}$ It permits a business combination leading to otherwise

less value both to consumers and to the firm in their new use than they

had in their former use.

Id. (footnote omitted).

The flaw in Campbell's argument is easily shown by recognizing that the defense operates as a one-way ratchet. The defense can permit business combinations to go forward that would otherwise be blocked, but it cannot provide a basis to block combinations that otherwise would be allowed. (In other words, the lack of a failing firm is not in itself a reason to block a business combination). The defense can only be neutral or under-enforcing on net.

26. One source dates the defense earlier than 1930. See Richard D. Friedman, Untangling the Failing Company Doctrine, 64 Tex. L. Rev. 1375, 1376 n.1 (1986). In International Shoe Co. v. FTC, 280 U.S. 291 (1930), the Court stated a two-part test for a successful failing-firm defense. First, the acquired firm must be facing the grave probability of a business failure. Second, the acquired firm must have had no other prospective purchasers.

27. In Citizen Publishing Co. v. United States, involving a merger of newspaper competitors, the Supreme Court added a third element to the defense: the firm asserting this defense must also be unable to reorganize successfully in a bankruptcy proceeding. 394 U.S. 131 (1969). Citizen Publishing is the first explicit recognition that the failing-firm defense serves as an alternative to the bankruptcy reorganization procedure for preserving the value in a declining industry.

Campbell's argument must therefore rest on a proposition that the optimal level of merger review necessarily is less in a business combination transaction involving a failing firm. That proposition depends on either (1) a failing firm's unique inability to bear enforcement costs or (2) an understanding that preserving a failing firm in the market is an efficient outcome in all cases, rendering any enforcement costs (including the possibility of false-positive results) wasteful. Either argument, if true, might support a conclusion of a lesser optimal level of antitrust enforcement.

Both arguments are wrong if applied uniquely to business combinations involving firms meeting some form of a failing-firm defense rather than generally across all business combinations. The first argument-a failing firm's unique inability to bear enforcement costs-ignores that the cost of merger review represents a tax on business combination transactions and relief from that cost represents a tax subsidy. The defense therefore provides a subsidy favoring business combinations involving weak firms. At the margins it provides an incentive to permit failure to occur that otherwise might be avoided.

The second efficiency argument holds that preserving a failing firm in the market is efficient in all cases. Under that argument, we should not tolerate antitrust enforcement costs beyond the minimum necessary to establish the application of the defense. This argument proves too much. The assumption that scrap or extra market use is less valuable than preserving the assets in the original market ignores that the firm's failure may be because the original use was less valued than alternatives. There are few assets with such single-purpose use that their exit necessarily equates to welfare loss. The frequent example of railroad tracks as the archetype of a single purpose asset is even misguided; track beds have been repurposed as valuable public resources. See, e.g., Western Maryland Rail Trail, Hancock 
intolerable market consolidation where there is reason to believe there is no other way to preserve the assets in the marketplace. ${ }^{28}$ The failing-firm defense is most frequently justified by a belief that if the failing firm was exiting the market, consolidation was occurring with or without the business combination. Therefore, the business combination will not harm competition. ${ }^{29}$

This syllogism supporting the defense suffers both from faulty logic and a questionable premise. A buyer who purchases assets and market share at a discount is advantaged vis-à-vis its competitors, which may lead to an anticompetitive increase in market dominance. ${ }^{30}$ The faulty premise becomes clear when one appreciates that whether a firm is failing, merely "flailing," or even substantially healthy, is a question of real uncertainty. ${ }^{31}$ The defense is therefore narrow: according to Section 11 of the 2010 Guidelines, any offer to purchase the assets for a price above the liquidation value is a "reasonable" offer that will undermine the defense. ${ }^{32}$ As a former FTC official said in support of the then-existing version of the failing-firm defense: "These requirements are strict. They are rarely all satisfied, and as a result, the defense is seldom successfully invoked."33

MD. Chamber Comm., http://www.westernmarylandrailtrail.org/WMRT/ [http:// perma.cc/DK8Y-SAF7] (last visited Nov. 19, 2015).

If preserving failing firms is efficient in all cases, no industry would be permitted to collapse-even if an industry, such as the manufacture of buggy-whips, has no meaningful place in a changing economy (Professor Jackson's example). See JACKSON, supra note 10. Moreover, there is no logical inflection point at which blocking a business combination becomes inappropriate. If preserving a failing firm is per se efficient, preventing a firm from reaching the point of imminent failure can be justified and preventing a firm from even beginning its decline might also be justified. Under that logical extension of the failing firm argument, all merger review is wasteful. Few commentators have taken such an extreme position. But see Fred S. McChesney, Defending the Failing-Firm Defense, 65 Neb. L. REv. 1, 5-12 (1986).

28. See 2010 Guidelines, supra note 11, pt. 11, at 32 (elements of defense operate to require imminent exit).

29. Id.

30. Without the asset sale, the market share of the exiting firm would be shared among the remaining firms, presumably being absorbed by the remaining firm with the greatest amount of idle productive capacity. The 2010 Guidelines seek to control for that concern by requiring that the assets are shopped to purchasers that present less concerns for an anticompetitive business combination. Id. pt. 11 , at $32 \&$ n. 16 .

31. David Scheffman, Malcolm Coate \& Louis Silvia, 20 Years of Merger Guidelines Enforcement at the FTC: An Economic Perspective 50 (2002), http://www.justice .gov/sites/default/files/atr/legacy/2007/07/11/12881.pdf [http://perma.cc/ 3MD6-4WWN] ("While th [e] concept of a failing firm is relatively straightforward, assessing whether or not a firm truly is failing can be quite challenging.").

32. 2010 Guidelines, supra note 11, pt. 11, at 32.

33. Debra A. Valentine, Gen. Counsel, Fed. Trade Comm'n Office of Policy Planning, Speech: Horizontal Issues: What's Happening and What's on the Horizon (Dec. 8, 1995), transcript available at https://www.ftc.gov/public-statements/ 1995/12/horizontal-issues-whats-happening-and-whats-horizon [https://perma .cc/LJ4Y-RTKZ] (discussing Section 5.1 of 1992 Horizontal Merger Guidelines). 
The original justification for the failing-firm defense does not relate to the economic efficiency of allowing the failing firm to merge despite competitive concerns. ${ }^{34}$ One year after the 1929 stock market crash, the Supreme Court took the view in International Shoe v. FTC that protecting the community in which a failing firm did business was a controlling rationale for a defense to a merger challenge:

In the light of the case thus disclosed of a corporation with resources so depleted and the prospect of rehabilitation so remote that it faced the grave probability of a business failure with resulting loss to its stockholders and injury to the communities where its plants were operated, we hold that the purchase of its capital stock by a competitor (there being no other prospective purchaser), not with a purpose to lessen competition, but to facilitate the accumulated business of the purchaser and with the effect of mitigating seriously injurious consequences otherwise probable, is not in contemplation of law prejudicial to the public and does not substantially lessen competition or restrain commerce within the intent of the Clayton Act. ${ }^{35}$

Decided nearly forty years later in 1969, the Court's statement of the defense in Citizen Publishing Co. v. United States has become the controlling judicial formulation. ${ }^{36}$ Citizen Publishing involved an effort to merge the

34. Not all commentators agree. For contrary views, see infra notes 58-68 and accompanying text.

35. Int'l Shoe Co. v. FTC, 280 U.S. 291, 302-03 (1930). The result in International Shoe is consistent with other Depression-era antitrust precedents and legislation. For example, the Court's decision in Appalachian Coals, Inc. v. United States, written in the same year, allowed firms to cartelize to protect employees and communities that would have suffered if the firms had been permitted to fail. 288 U.S. 344 (1933), overruled by Copperweld Corp. v. Independence Tube Corp., 467 U.S. 752 (1984). International Shoe and Appalachian Coals preceded the National Industrial Recovery Act, which also subordinated antitrust law to economic recovery goals. See generally Spencer Weber Waller, Thurman Arnold: A Biography 83-84 (2005) (describing antitrust enforcement during National Recovery Administration). Language from International Shoe has been misinterpreted to support an efficiency justification for the Court's holding. See Campbell, supra note 25, at 4 ("to facilitate the accumulated business of the purchaser" (quoting Int'l Shoe, 280 U.S. at 302-03)). That interpretation is misguided as an historical matter-economic efficiency rationales as they have been understood since the 1970s were not part of Supreme Court antitrust precedents in 1930 - and as an interpretive matter. The relevant passage from International Shoe starts with the goal of avoiding "loss to [ ] stockholders and injury to the communities" and continues to observe the salutary benefits of "mitigating seriously injurious consequences otherwise probable" (if the merger is not allowed). See 280 U.S. at 302-03.

36. Courts have occasionally appeared to deviate from the Citizen Publishing rule. Five years later the Supreme Court appeared to return to the two-element International Shoe framework in a merger involving coal-mining companies. The actual importance of that development in United States v. General Dynamics, Corp. is debatable. See 415 U.S. 486 (1974). The General Dynamics Court referenced the defense in passing, holding on other grounds that the merger did not violate the Clayton Act. Other courts that have ostensibly failed to follow the additional third 
operations of competing newspapers. ${ }^{37}$ On appeal, the Supreme Court had no difficulty concluding the joint operation agreement violated the Clayton Act, but considered the argument that Citizen Publishing was a failing company. The district court had found as a factual matter that "Citizen Publishing was not then on the verge of going out of business, nor was there a serious probability at that time that Citizen Publishing would terminate its business and liquidate its assets unless Star Publishing and Citizen Publishing entered into the operating agreement." 38 Recognizing the success of the bankruptcy reorganization scheme under the then-existing Bankruptcy Act, the Court added the "inability to reorganize in bankruptcy" element to the International Shoe rule:

[W] e know from the broad experience of the business community since 1930, the year when the International Shoe case was decided, that companies reorganized through receivership, or through Chapter X or Chapter XI of the Bankruptcy Act often emerged as strong competitive companies. The prospects of reorganization of the Citizen in 1940 would have had to be dim or nonexistent to make the failing company doctrine applicable to this case. ${ }^{39}$

Since Citizen Publishing, courts generally have included the requirement of an inability to reorganize in bankruptcy in their statements of the defense. ${ }^{40}$ The Court in Citizen Publishing did not give a reason for adding this third element. The opinion is susceptible to a reading that the Court was generically hostile to the defense and sought to cabin it. ${ }^{41}$ Building on that understanding, the best justification for limiting the failing-firm

element from Citizen Publishing appear to have concluded the element was inapplicable on the particular facts rather than relying on a holding that the element should not be applied.

37. Citizen Publ'g Co. v. United States, 394 U.S. 131, 133 (1969).

38. Id. at 137 (internal quotation marks omitted). The Court affirmed that factual conclusion: "There is no indication that the owners of the Citizen were contemplating a liquidation. They never sought to sell the Citizen and there is no evidence that the joint operating agreement was the last straw at which the Citizen grasped. Indeed the Citizen continued to be a significant threat to the Star." Id.

39. Id. at 138. The Court also noted that the burden of proving the defense was on the party asserting it and that Citizen Publishing had failed to meet its burden. Id. at 138-39.

40. Judge Posner has argued that the inability to reorganize in bankruptcy element was inappropriately grafted into the defense because the purpose of the defense is to keep firms from entering bankruptcy. Richard A. Posner, Antitrust Law (2d ed. 2001). Posner's view recognizes the alternative nature of reorganization by merger and reorganization through Chapter 11. See also, e.g., Austin, supra note 24, at 165-74. Requiring an inability to reorganize as an element of the defense might thrust firms into Chapter 11 first and allow the failing-firm defense only where that reorganization has proved unsuccessful.

41. See, e.g., Citizen Publishing, 394 U.S. at 139 ("We confine the failing company doctrine to its present narrow scope."). This read of the rationale behind Citizen Publishing is supported by the view that the Warren Court was particularly hostile to merger activity in the 1960s. See United States v. Von's Grocery Co., 384 
defense where bankruptcy reorganization is possible is that bankruptcy reorganizations are preferred to business combinations as a means to rescue a firm faced with operating challenges. ${ }^{42}$ Citizen Publishing is best read as repudiating Depression-era precedents that favored industrial survival over consumer interests. ${ }^{43}$

More recent decisions follow the Citizen Publishing rule. ${ }^{44}$ The Sixth Circuit reviewed a vertical merger in the cement industry in United States Steel Corp. v. FTC, ${ }^{45}$ holding that the defense was not met on the basis of the merging parties' failure to prove an inability to reorganize in bankruptcy. In California $v$. Sutter Health, ${ }^{46}$ the Ninth Circuit discussed the inability-to-reorganize element in depth, finding testimony by a financial expert that bankruptcy proceedings would likely result in liquidation convincing. The Citizen Publishing rule also controlled the development of the defense in the Horizontal Merger Guidelines. ${ }^{47}$

\section{The Defense in the Guidelines}

By the time of the 1992 Guidelines, the statement of the failing-firm defense had expanded to include four elements. A firm was required to show (1) it would be unable to meet its financial obligations in the near future; (2) it would not be able to reorganize successfully under Chapter

U.S. 270, 301 (1966) (Stewart, J., dissenting) ("The sole consistency that I can find is that in litigation under [Section] 7, the Government always wins.").

42. This prioritizing would respect the empirical result reached by LoPucki that full reorganizations tend to produce greater long-term value than do business combinations that are not subjected to full stake-holder involvement and court review. See Lynn M. LoPucki, Courting Failure: How Competition for Big Cases Is Corrupting the Bankruptcy Courts 167-80 (2005); LoPucki \& Doherty, supra note 3 , at 1 .

43. See, e.g., Appalachian Coals, Inc. v. United States, 288 U.S. 344 (1933), overruled by Copperweld Corp. v. Independence Tube Corp., 467 U.S. 752 (1984); Int'l Shoe Co. v. FTC, 280 U.S. 291 (1930). This view is not a necessary interpretation: if, based on an appreciation of the empirical reality that LoPucki and others have demonstrated, Citizen Publishing preferred a full bankruptcy reorganization to a sale in order to return greater value to stake-holders, it may suggest a willingness to subordinate consumer interests. However, the facts before the Court did not involve a distinction between a hasty sale and a reorganization, but rather between a joint management and profit-sharing agreement and a reorganization. If anything, the choice the Court preferred (reorganization) subordinated stake-holder interests to those of consumers.

44. Thomas D. Fina \& Vishal Mehta, The Failing Firm Defense: Alive and Well, Antitrust Source, Aug. 2011, at 1, available at http://www.americanbar.org/content/dam/aba/publishing/antitrust_source/aug11_fina_7_26f.authcheckdam.pdf [http://perma.cc/Q8ZV-ZSUG] ("Since its debut in 1930, the failing firm defense has remained remarkably consistent in its formulation.").

45. 426 F.2d 592 (6th Cir. 1970).

46. 217 F.3d 846 (9th Cir. 2000) (unpublished table decision).

47. See 2010 Guidelines, supra note 11. The first version of the Guidelines, published in 1968, provided for a failing-firm defense that was modeled on the two-element International Shoe test. Every Guidelines' revision, including the current 2010 version, has included a version of the failing-firm defense. 
11 of the Bankruptcy Code; (3) it had made unsuccessful good-faith efforts to elicit reasonable alternative offers that would keep its tangible and intangible assets in the relevant market and pose a less severe danger to competition than would the proposed merger; and (4) in the absence of the acquisition, its assets would soon exit the relevant market. ${ }^{48}$

Under the Guidelines re-written and promulgated by the Department of Justice and FTG in 2010:

[A]ll of the following circumstances [must be] met: (1) the allegedly failing firm would be unable to meet its financial obligations in the near future; (2) it would not be able to reorganize successfully under Chapter 11 of the Bankruptcy Act; and (3) it has made unsuccessful good-faith efforts to elicit reasonable alternative offers that would keep its tangible and intangible assets in the relevant market and pose a less severe danger to competition than does the proposed merger. ${ }^{49}$

The 2010 Guidelines eliminated the fourth "imminent exit" element from the statement of the defense in 1992.50 It is unlikely that in practice the elimination of the imminent-exit element in the 2010 Guidelines will have

48. The 1992 Guidelines' version of the failing-firm defense was, on its face, less permissive than the prevailing judicial statement of the defense. The first Guidelines element alters the first element from International Shoe-"grave probability of business failure"-in two ways. It added what could best be called an imminence requirement and it split the element into two. Guidelines element one was an imminent insolvency requirement, and Guidelines element four was an imminent exiting assets requirement. Guidelines element two is borrowed directly from Citizen Publishing, demonstrating that contrary to some holdings (including Supreme Court's General Dynamics decision) the agencies believed the inability to reorganize in bankruptcy to be a requirement distinct from imminent business failure. Guidelines element three continued to approximate the second International Shoe element, requiring the merging parties to establish a lack of reasonable offers that did not present the same competitive concerns.

49. See 2010 Guidelines, supra note 11 , at 32 .

50. The 2010 Guidelines' elimination of the "imminent exit" element is intriguing. On one hand, that element is the very core of the defense-so much so that in 2009 Ken Heyer and Sheldon Kimmel proposed in passing that the defense might better be called the "exiting assets" defense. They argued that the defense should fail if the assets would remain in the market in the absence of the merger, whether under independent ownership or after a less anticompetitive sale to an alternative buyer. The rationale for having a failing-firm defense at all depends on the imminence of exit. In a case in which that element is not met, a basic merger efficiencies analysis will accomplish the purpose of weighing the harms from the merger against its benefits. At first blush, that change should make the failing firm defense easier to establish than prior versions of the defense. A firm threatened with equity insolvency (defined as the inability to pay debts as they come due), is not necessarily a firm on the verge of failure and exit, which both International Shoe and the 1968 Guidelines had required in their first element, and the 1992 Guidelines had required in the now-eliminated fourth element. See 11 U.S.C. $\S 303(\mathrm{~h})(1)$ (2012) (listing first element). 
a substantial impact on the use of the failing-firm defense as applied by the enforcement agencies. ${ }^{51}$

The 2010 Guidelines maintain the long-standing clarification that a "reasonable alternative offer" for the assets or stock of the failing firm includes "[a]ny offer to purchase the assets of the failing firm for a price above the liquidation value of those assets . . ."52 This definition is a low bar. To the agencies' views, nearly any would-be buyer willing to operate the assets in the market of concern will defeat the defense. ${ }^{53}$ The failingfirm defense under the Guidelines thus operates only to preserve productive capacity in the market and does not contemplate benefits to constituents of the firm. The reasonable-alternative-offer rule establishes the modern antitrust-law view that consumer interests take priority over investor interests. This result contrasts with and improves on the original International Shoe rationale for the judicially-created defense. ${ }^{54}$

The any-price-above-liquidation-value standard is best explained by an understanding that any increment of value above liquidation value is justified by an expectation of market power that may create opportunity and incentive for the post-combination firm to engage in non-competitive output and pricing decisions. If a claim of merger-specific efficiencies ${ }^{55}$ overcomes that concern, the merging parties can rely on an efficiencies

51. It is difficult to imagine a firm that is both facing equity insolvency and unlikely to be successful in Chapter 11 reorganization that is not also facing imminent exit from the market of concern in the absence of an otherwise anticompetitive merger. There is a scenario under which the elimination might ease the defense's availability. Courts are not bound by the Guidelines, but may find them persuasive. The Horizontal Merger Guidelines do not have the force of law, but they do express the views of two expert agencies, announced after a notice-andcomment consideration process, as to the appropriate interpretation and application of the antitrust laws' anti-merger provisions. See generally Greene, supra note 23. Judicial reliance on the Guidelines can be expected to function as a one-way ratchet. Rules that support non-enforcement will be more persuasive (as abdications of enforcement power) than will be rules that support aggressive enforcement (which reflect the agencies' enforcement ambitions).

This result follows from the lack of competing guidelines for merging parties that seek application of the failing-firm defense. A court might reasonably decline to apply the second element of the Guidelines' formulation, relying instead on the original statement of the defense and the authorities that have hewed to that formulation, and not require the merging parties to demonstrate the Citizen Publishing requirement of an inability to reorganize in Chapter 11 . That same court might nonetheless be persuaded by the federal enforcement agencies' announcement in the 2010 Guidelines that the defense could be applied without the imminent-exit element. Under such a scenario, a firm facing equity insolvency, for which Chapter 11 is a realistic option, and which might-whether through bankruptcy or otherwise-remain as a competitor in the marketplace for the foreseeable future, could nonetheless avail itself of the failing-firm defense.

52. See 2010 Guidelines, supra note 11 , at 32 n.16.

53. "Liquidation," as it is used here, refers to a sale for any use other than production in the current market of concern.

54. See supra note 35 and accompanying text. This conflicts with bankruptcy law preferences for investor interests. See infra note 240.

55. Economic benefits that could not be achieved without the merger. 
defense. ${ }^{56}$ Such a business combination would not need the failing-firm defense. The efficiencies defense also would operate to permit business combinations that were valuable because of cost-reducing and output-enhancing synergies. ${ }^{57}$ The liquidation-value standard ensures the failingfirm defense will only apply if there is no anticompetitive effect at all from the combination or merger-specific efficiencies overcome the harms from increased concentration.

\section{Rationales for the Defense}

Two leading rationales support the failing-firm defense. First, the business combination involving a failing firm may have no significant adverse effect on competition or may be efficient relative to the alternative (the firm's exit). Second, the defense can be justified on the basis of social benefits because it serves the interests of stockholders, creditors, and employees. ${ }^{58}$

\section{a. No Competitive Effect}

The 2010 Guidelines provide an example of the no-competitive-effect rationale:

[A] merger is not likely to enhance market power if imminent failure ... of one of the merging firms would cause the assets of that firm to exit the relevant market. . . . If the relevant assets would otherwise exit the market, customers are not worse off af-

56. See 2010 Guidelines, supra note 11, pt. 10, at 29 (“[A] primary benefit of mergers to the economy is their potential to generate significant efficiencies and thus enhance the merged firm's ability and incentive to compete . . .."); see also, e.g., FTC v. H.J. Heinz Co., 246 F.3d 708, 720 (D.C. Cir. 2001); FTC v. Univ. Health, Inc., 938 F.2d 1206 (11th Cir. 1991); FTC v. Staples, Inc., 970 F. Supp. 1066 (D.D.C. 1997).

57. See 2010 Guidelines, supra note 11, pt. 10, at 29-30 (combining complementary assets, reducing costs, creating new maverick firm).

58. See Henry B. McFarland \& Philip B. Nelson, Failing Firms and Declining Industries, 3 Issues Competition L. \& Pol'y 1691 (2008), available at http://ssrn .com/abstract=1529815 [http://perma.cc/G5MF-F86R]. A naïve commenter may be ambivalent as between the two rationales. According to one member of the U.S. Senate, speaking about American Airlines' 2001 business combination with debtor Trans-World Airlines: "American has come to TWA's rescue, which I support. It will save jobs, and protect consumers who would have lost service." The same senator also stated, "[w]ithout American's efforts, TWA would have been forced to close its doors, leaving thousands of employees out of work, and more important, thousands of travelers without service. The point is that we are not losing a competitor that would not have been lost anyway." Effects of the American Airlines/TWA Transaction and Other Airline Industry Consolidation on Competition and the Consumer: Hearing Before the S. Comm. on Commerce, Sci. EJ Transp., 107th Cong. 3 (2001) [hereinafter Effects of American Airlines/TWA Transaction Hearing] (prepared statement of Sen. Ernest F. Hollings, Member of S. Comm. on Commerce, Sci. \& Transp.), available at http://www.gpo.gov/fdsys/pkg/CHRG-107shrg86771/html/ CHRG-107shrg86771.htm [http://perma.cc/MR9W-HP8V]. Both rationales are reflected in the senator's statement of support for the business combination. 
ter the merger than they would have been had the merger been enjoined. 59

Heyer and Kimmel argue for this rationale in their analysis published during the 2010 Guidelines' drafting. ${ }^{60}$ Where the assets would otherwise exit the market, "by definition these assets would be providing no competitive constraint in the market at all." 61 Retaining the assets in the market preserves present capacity, which gives firms incentives to maintain output levels. ${ }^{62}$ In contrast, the decline in capacity that will occur if the firm is permitted to fail will decrease supply-side elasticity, making non-competitive price and output decisions profitable. ${ }^{63}$

This rationale is not indubitably correct in all circumstances. It is possible to imagine a circumstance in which the assets of the failing firm are purchased by a dominant competitor. The dominant acquiring firm may face incentives (1) to idle the assets ${ }^{64}$ or (2) to deploy them to deter or to punish pro-competitive price reductions, output increases, or entry decisions by competitors or would-be competitors. In such a case, even while nominally maintaining industry capacity, the business combination would harm, rather than benefit, competition in the industry. ${ }^{65}$

59. See 2010 Guidelines, supra note 11 , pt. 11, at 32.

60. See Ken Heyer \& Sheldon Kimmel, Econ. Analysis Grp., EAG 09-1, Merger Review of Firms in Financial Distress (2009), available at http://www .justice.gov/sites/default/files/atr/legacy/2009/03/31/244098.pdf [http://per ma.cc/SFP8-URNQ].

61. See id. at 6.

62. Fundamental antitrust economics establishes that maintaining output levels protects against concentration-caused price increases. See generally RoberT S. Pindyck \& Daniel L. Rubinfeld, Microeconomics 263-66 (Valerie Ashton ed., 3d ed. 1994).

63. Some have read the Supreme Court's opinion in International Shoe to represent an efficiency basis for the failing-firm defense. That Court noted that the acquiring firm had been forced to cancel orders it did not have the capacity to fill, such that "the controlling purpose of the International in [seeking to merge] was to secure additional factories, which it could not itself build with sufficient speed ... ." Int'l Shoe Co. v. FTC, 280 U.S. 291, 301 (1930). The acquirer, International Shoe, expected to profit from the merger by increasing output in a way it could not "but for" the merger. That output increase, with its attendant decrease in prices, represents a benefit to consumers from keeping the failing firm's assets in operation in the industry in question.

64. For a real-world example, Hercules Offshore, Inc. purchased competitor Seahawk Drilling, Inc. in 2011 in a transaction later characterized by Hercules' counsel as presenting a "high combined market share" and likely to lead to "a second request and a protracted investigation." Fina \& Mehta, supra note 44, at 4 . According to the Wall Street Journal, after a decline in drilling, Hercules returned to profitability after selling "many of its older rigs, including some for scrap," while “[o]thers had been 'stacked,' or idle ...." Alison Sider \& Ben Fox Rubin, Hercules Offshore Swings to Surprise Fourth-Quarter Profit, Wall ST. J., Feb. 12, 2013, http:// online.wsj.com/news/articles/SB10001424127887324880504578300233453952480 [http://perma.cc/KP36-7ZNJ].

65. Another example of potential for harm in a business combination involving a failing firm involves an acquiring firm that seeks to effect a business combination in spite of a lack of merger-specific efficiencies. Heyer and Kimmel argue the 


\section{b. Non-Economic Benefits}

The most natural reading of International Shoe, particularly if undertaken with an understanding of contemporary antitrust precedents and political realities in the years following the 1929 stock market crash, holds that the defense was created to protect a firm's constituents other than consumers, including shareholders, employees, and communities. Richard Posner has subscribed to this interpretation. ${ }^{66}$ Non-economic considerations are of demonstrable interest to Congress when it acts under its legislative prerogative to evaluate proposed mergers. For example, congressional hearings held at the time of the 2001 acquisition of TransWorld Airlines (TWA) by competitor American Airlines included substantial discussion of the effect of TWA's expected failure on employees and communities. ${ }^{67}$

Political realities of executive antitrust enforcement suggest that noneconomic interests enter into enforcement decisions as well. For example, the recent US Airways/American Airlines merger was subject to a strong Justice Department challenge and did not involve a viable failing-firm defense. Nonetheless, the challenge settled on what many have argued were benign terms following arguments by state government leaders and individual members of Congress that the merger was good for the companies, their employees, and affected communities.

The social benefits justification underlies other successful mergers as well. The sale of Chrysler Corporation to Fiat S.p.A. in 2009 during the course of the Chrysler bankruptcy proceeding can best be explained as an effort to preserve an economically important manufacturer during a time of national economic distress. Bank mergers were likewise permitted to proceed during the time of the financial crisis with limited antitrust review. ${ }^{68}$

acquirer anticipates dividends from increased prices, which suggests the acquiring firm knows that (1) the imminent exit story is false and (2) the acquisition will give it market power that it would not have in the absence of the acquisition. Heyer and Kimmel suggest that the acquirer will exercise that market power by shutting down the acquired firm. See Heyer \& Kimmel, supra note 60. For example, as longtime airline industry observer Michael Levine testified to Congress in the context of the American-TWA transaction, "I do not think it is a particularly good deal for American and its shareholders .... American wants TWA's assets partly because ... network size and scope matter and American would like to grow a little bit, to move up on United." Effects American Airlines/TWA Transaction Hearing, supra note 58, at 36 (statement of Michael Levine, Adjunct Professor of Law, Harvard Law School).

66. Posner, supra note 40. Others disagree. The federal enforcement agencies have not favored the social benefits rationale for the defense. The argument that social costs should be taken into account was made in hearings prior to the 1997 amendments to the Guidelines, but the agencies did not elect to include such language in the Guidelines.

67. See, e.g., Effects American Airlines/TWA Transaction Hearing, supra note 58, at 5 (statement of Hon. Louise McIntosh Slaughter).

68. As a matter of a federal statute limited to banks, social benefits are held to outweigh efficiency considerations. The Bank Merger Act of 1966 permits federal 


\section{Business Combinations Under the Bankruptcy Code}

In the prior two subparts, this Article explained antitrust law's treatment of mergers and asset sales, showing that antitrust law has developed in the years since the 1930s to limit the availability of mergers and asset sales where consumers might be harmed, even if the effect was to permit a company to exit the market. This Subpart shows the bankruptcy law treatment of business combinations, both as part of the plan of reorganization and as out of the ordinary course of business asset sales that are part of the process of reshuffling the estate in preparation for the reorganization plan.

The Bankruptcy Code provides two mechanisms for allowing business combinations under bankruptcy court supervision. ${ }^{69}$ First is an out of the ordinary course of business sale of assets authorized by Bankruptcy Code Section 363(b). ${ }^{70}$ Second is a plan sale under Bankruptcy Code Section 1123(a). ${ }^{71}$ Either might be used in any particular case; as the bankruptcy court noted in In re Gulf States Oil Corp., "[t] he Bankruptcy Code does not provide any explicit guidance to determine when [Section] 363(b) is the appropriate procedure and when [Section] 1123 is the appropriate procedure."72

First, Chapter 11 provides for bankruptcy business combinations as part of a plan of reorganization under Bankruptcy Code Section 1123. The plan "shall" provide adequate means for its implementation, with the sale of estate property being one of the listed alternatives for accomplishing this requirement; in addition, "a plan may ... provide for the sale of all or substantially all of the property of the estate . . ."73 A plan sale under Section 1123 protects diffuse stakeholders through detailed procedures and requirements that must be met for plan approval. Non-stakeholder interests are not specifically protected, but concern for the success of the plan sale ensures relevant regulatory policies become part of the bankruptcy court's decision process on confirmation.

enforcement agencies to approve even anticompetitive transactions if the federal agencies find that the anticompetitive effects of the proposed transactions are outweighed by the probable effect of the transaction in meeting the "convenience and needs" of the community to be served. 12 U.S.C. $§ 1828$ (c) (2), (5) (A) (2012). Like the failing-firm defense, the burden of proving the social benefit defense is on the merging banks. See United States v. First City Nat'l Bank, 386 U.S. 361 (1967). See generally Terry Calvani \& Cecil Saehoon Chung, Antitrust Analysis of Bank Mergers: A Survey of Recent Developments, FindLaw.com (Mar. 26, 2008), http:// corporate.findlaw.com/finance/antitrust-analysis-of-bank-mergers-a-survey-of-recent.html [http://perma.cc/25HN-C7PT]. 2009).

69. See In re Gulf Coast Oil Corp., 404 B.R. 407, 414-15 (Bankr. S.D. Tex.

70. See infra note 72 and accompanying text.

71. See infra notes 72-73, 93 and accompanying text.

72. 404 B.R. at 415.

73. 11 U.S.C. $§ 1123(\mathrm{~b})(4)$ (2012). 
Second, although pre-Code law was mixed on the subject, ${ }^{74}$ modern interpretations of the Bankruptcy Code also allow business combinations under Section 363(b), which provides for sales of estate property "other than in the ordinary course of business" with court approval after notice and a hearing. ${ }^{75}$ Section 363 (b) provides little specific guidance as to its reach and operation. ${ }^{76}$ Some courts have been confused as to the differences between a plan sale and a Section 363(b) sale, although the better interpretation of the statute is to consider the 363 (b) sale to be available before a plan is approved and the plan sale to be available only with full plan approval. ${ }^{77}$

The 363(b) sale procedure offers two substantial benefits from the perspective of the parties to a business combination transaction. First, in the normal course judicial scrutiny and stakeholder involvement is less than if the sale were conducted as part of the reorganization plan. ${ }^{78}$ Second, opportunities for regulatory interference, including procedures for antitrust review, are curtailed. ${ }^{79}$ The flip sides of both coins suggest less protection for both stakeholders and non-stakeholders, depending on reg-

74. In Fidelity Assurance Ass'n v. Sims, the Supreme Court reversed the lower courts' decisions declining to dismiss a reorganization petition for bad faith under the then-in-force Bankruptcy Act. 318 U.S. 608, 618-19 (1943). The Court noted it was clear from the petition that reorganization could not succeed and that "Congress did not intend resort to Chapter X [the predecessor to the Bankruptcy Code's Chapter 11] to be had for the mere purpose of liquidation." Id. at 621. Consistent with the Court's approach, the Third Circuit limited pre-plan asset sales to "emergencies where there is imminent danger that the assets of the ailing business will be lost if prompt action is not taken." In re Solar Mfg. Corp., 176 F.2d 493, 494 (3d Cir. 1949) (providing examples of sufficient emergency such as "a warehouse full of meat in storage" and lack of "money to buy ice"). Other circuits interpreted Sims narrowly, permitting pre-plan business combinations to take place in bankruptcy. See, e.g., Int'l Bank of Miami v. Brock (In re Dania Corp.), 400 F.2d 833, 836 (4th Cir. 1968); Patent Cereals v. Flynn, 149 F.2d 711, 712 (2d Cir. 1945) ("[W]e think that it can make no difference whether a sale of the debtor's property has preceded or is made a part of the plan of reorganization.").

75. 11 U.S.C. $\$ 363$ (b) (2012). The section literally provides for sale by the bankruptcy trustee. In a Chapter 11 bankruptcy the debtor is empowered to act as a trustee. See id. $\S 1107(\mathrm{a})$.

76. See Jacoby \& Janger, supra note 4.

77. See In re Golf LLC, 322 B.R. 874, 877 (Bankr. D. Neb. 2004) (noting "the distinction between the purposes of $\S 363$ and $\S \S 1123$ and 1141 " as one between "asset sales prior to plan approval" and "sales made pursuant to a plan"); George W. Kuney, Misinterpreting Bankruptcy Code Section 363(f) and Undermining the Chapter 11 Process, 76 Ам. Bankr. L.J. 235, 236 (2002). But see In re Coastal Indus., Inc., 63 B.R. 361, 366-69 (Bankr. N.D. Ohio 1986) (equating non-plan sales under Sections 363 and 1123(a)(5)(d)); In re Wood, 47 B.R. 774, 777 (Bankr. W.D. Wis. 1985) (finding non-plan sales may occur under 363(b) or 1123(b)(4)); In re WHET, Inc., 12 B.R. 743, 750 (Bankr. D. Mass. 1981) (noting permissive nature of 1123(b) (4) allows for pre-plan sales under section).

78. See William T. Bodoh, John W. Kennedy \& Joseph P. Mulligan, The Parameters of the Non-Plan Liquidating Chapter Eleven: Refining the Lionel Standard, 9 BANKR. Dev. J. 1, 3-4 (1992).

79. Since 1994, Section 363(b) has included a provision for notification to the antitrust authorities of a business combination implicating the Hart-Scott-Rodino 
ulatory oversight, which is less in the case of a 363 (b) sale than in the case of a plan sale.

\section{Asset Sales as Part of the Plan of Reorganization}

Business combinations may be included in reorganization plans under Bankruptcy Code Sections 1123 and 1129. ${ }^{80}$ A reorganization plan, including any business combination provided for, requires court approval through the process of "confirmation." ${ }^{1}$ The process for achieving that approval is detailed and involved. It requires notice and a hearing, at which "any party in interest" may object to confirmation. ${ }^{82}$ The plan confirmation process provides for the participation of all stakeholders and imposes requirements that cabin the bankruptcy court's discretion. That participation is provided for by a detailed scheme of rival reorganization plans, disclosure, and voting. ${ }^{83}$ Further protection is provided by the "feasibility" requirement: Section 1129 permits plan confirmation only if "[c] onfirmation of the plan is not likely to be followed by the liquidation, or the need for further financial reorganization, of the debtor . . .."84

A successful vote by classes of stakeholders is a necessary, but not sufficient, condition to plan approval. A debtor seeking court approval of a plan that includes a merger also bears the burden to establish, among other requirements, that the plan is not likely to be followed by a future liquidation or reorganization-that is, that the plan is "feasible." 85 The feasibility requirement is invoked when courts consider whether to confirm plans proposed to be effected by a business combination. ${ }^{86}$

Feasibility is undermined in the presence of regulatory limitations that increase the difficulty of a particular constituent element of the plan. ${ }^{87}$ Bankruptcy courts treat the possibility of an antitrust challenge to

Act, with a foreshortened waiting period for premerger review. 11 U.S.C. $\S 363$ (b) (2) (B); see also H.R. Rep. No. 103-835, at 17-18 (1994).

80. Section 1123 dictates the required and permissible contents of a plan and Section 1129 establishes requirements for its approval. See 11 U.S.C. §1123; id. $\S 1129$.

81. See id. $\$ 1129$.

82. See id. $\S 1128(\mathrm{a})$, (b).

83. See id. $\$ 1125$ (disclosure requirements); id. $\$ 1126$ (providing supermajority voting); $i d . \S 1129$ (providing requirements for plan confirmation); see also In re Smurfit-Stone Container Corp., No. 09-10235(BLS), 2010 WL 2403793, at *10 (Bankr. D. Del. June 11, 2010) ("An asset sale pursuant to a plan of reorganization provides for a heightened degree of notice and disclosure surrounding all aspects of the sale, and allows the affected creditors to vote to accept or reject the plan, including the asset sale.").

84. 11 U.S.C. $\$ 1129$ (a) (11).

85. See id.

86. See, e.g., In re River Capital Corp., 155 B.R. 382, 387 (Bankr. E.D. Va. 1991) (overruling objections to confirmation and stating "the court determines that the inclusion of a merger or acquisition option does not render the plan infeasible").

87. See In re TCI 2 Holdings, LLC, 428 B.R. 117, 154, 155 (Bankr. D.N.J. 2010) (explaining "proponents of [] Plan must also show that the new owners of the Reorganized Debtors will not face material hurdles to achieve the necessary regula- 
a proposed business combination as a regulatory impediment that speaks to the question of a plan's likely successful implementation. For example, In re TCI 2 Holdings, $L L C$ involved a casino bankruptcy proposed to be resolved through a business combination. The combination faced a feasibility attack based on the prospect of antitrust challenge and a similar state-law licensure-related proceeding testing "undue economic concentration." 88 The Bankruptcy Court for the District of New Jersey engaged in a detailed analysis of both the substance and the procedure of the likely challenges before concluding that their prospects did not undermine feasibility. 89

\section{Asset Sales Under 11 U.S.C. 363(b) and "Sub-Rosa" Plans}

Bankruptcy Code Section 363(b) allows business combinations out of the ordinary course of business with court approval as part of the reorganization process. ${ }^{90}$ Although "[t]he drafters of [S]ection 363 probably thought in terms of sales of particular assets, not entire businesses,"91 courts regularly approve business combinations under the section, even in cases as large as the Lehman Brothers and Chrysler Motors bankruptcies. ${ }^{92}$ Section 363 (b) asset sales frequently are preferred by debtors and potential purchasers because they are subject to lesser interference by stakeholders in the bankruptcy estate. ${ }^{93}$ Like plan sales, Section 363(b) sales can serve as "means for the plan's implementation" under Section $1123(\mathrm{a})(5) .{ }^{94}$

tory approvals" and concluding plan was feasible after finding "a reasonable prospect of success ... to obtain regulatory approval").

88. See id. at 174 .

89. See id. at 178 .

90. 11 U.S.C. § 363 (b) (2012).

91. LoPucki, supra note 42, at 168 (citing H.R. ReP. No. 95-595 (1977)).

92. See In re Lehman Bros. Holdings Inc., 445 B.R. 143, 180-81 (Bankr. S.D.N.Y. 2011) (citing Ind. State Police Pension Trust v. Chrysler LLC (In re Chrysler LLC), 576 F.3d 108, 118-19 (2d Cir. 2009)) (discussing 363(b) sale order), aff'd in part, rev'd in part by 478 B.R. 570 (S.D.N.Y. 2012).

93. The limitation on realistic stakeholder involvement is such that some have argued that Section 363 sales are sub-rosa reorganization plans. As a famous recent example, in the Chrysler Corp. bankruptcy case in 2009, Fiat S.p.A. purchased a substantial stake in Chrysler Corp. through a Section 363(b) out of the ordinarycourse-of-business asset sale, largely obviating the need for a full Chapter 11 reorganization at all. See generally Benjamin A. Berringer, Note, "It's All Just a Little Bit of History Repeating:" An Examination of the Chrysler and GM Bankruptcies and Their Implications for Future Chapter 11 Reorganizations, 7 N.Y.U. J.L. \& Bus. 361, 361-62 (2010). Section 363(b) sales offer a second advantage: to incent a sale, bankruptcy courts frequently exercise their discretion to sell the property free and clear of interests in, including liens on, the assets in question. 11 U.S.C. $\$ 363(\mathrm{f})-(\mathrm{g})$.

94. See, e.g., Joint Plan of Reorganization $\S 7.1$, at 18, In re Seahawk Drilling, Inc., No. 11-20089-RSS (Bankr. S.D. Tex. May 20, 2011), available at http://www .sec.gov/Archives/edgar/data/1452384/000119312511146870/dex991.htm

[http://perma.cc/SP6Z-EEQU] ("Pursuant to the terms of this Plan, the Sale Proceeds and the proceeds from the liquidation of the Excluded Assets will be distributed to holders of Allowed Claims and Interests."). 
Business combinations under Section 363(b) offer less process for challenge by stakeholders or review by regulators or other interested parties. In contrast with the detailed disclosure, voting, and confirmation requirements for business combinations effected as part of a reorganization plan, business combinations under 363(b) require "notice and a hearing." 95 In contrast with the possibility of full antitrust review requiring "at least 30 days" that the court entertained in TCI 2 Holdings, the procedures for antitrust review of a 363(b) business combination are cut approximately in half. 96

Studies of 363(b) business combinations have observed their impact on asset prices and potential disenfranchisement of stakeholders. ${ }^{97}$ These sales are sometimes called "sub rosa" plans, because they have the effect of wrapping up many of the issues presented by the bankruptcy proceeding without providing the due process required for plan confirmation. For this reason, courts historically were suspicious of non-plan business combinations. In an early treatment interpreting the 1938 Bankruptcy Act, the Supreme Court held a reorganization petition filed "for the mere purpose of liquidation" was in bad faith. ${ }^{98}$ Later courts allowed pre-plan sales when the plans were found to be "fair and equitable" with reference to the pre-plan sale, ${ }^{99}$ where "justifiable cause" was present, ${ }^{100}$ or when the sale was justified by an emergency. ${ }^{101}$

Modern courts and commenters also have recognized the danger that 363 (b) sales benefit a favored bidder and management of the debtor at the expense of other bidders and stakeholders. ${ }^{102}$ A 2007 empirical study of the effect of 363(b) asset sales concluded that fire sales produce less value for stake-holders than do successful reorganizations. ${ }^{103}$ A recent 2014 study compared 363(b) sales to "plan sales"-those conducted as

95. 11 U.S.C. $\$ 363(\mathrm{~b})(1)$; see also In re Smurfit-Stone Container Corp., No. 09-10235(BLS), 2010 WL 2403793, at*10 (Bankr. D. Del. June 11, 2010) (contrasting "protections for affected parties" under 363(b) versus under a reorganization plan); In re Orfa Corp. of Phila., Nos. 90-11253S, 90-11254S \& 90-11255S, 1991 WL 225985, at *5 (Bankr. E.D. Pa. Oct. 30, 1991) (explaining plan sale incorporates same process of $363(\mathrm{~b})$ and also includes disclosure and voting requirements).

96. Compare 15 U.S.C. $§ 18 \mathrm{a}(\mathrm{b})$, (e) (2) (2012) (providing thirty-day waiting period extendable by thirty additional days at enforcement agencies' discretion), with 11 U.S.C. $\$ 363(\mathrm{~b})(2)$ (B), and 15 U.S.C. $\$ 18 \mathrm{a}(\mathrm{e})$ (2) (providing fifteen-day waiting period extendable by ten additional days at enforcement agencies' discretion).

97. See, e.g., Bodoh et al., supra note 78, at 3-4, 8-14.

98. Fidelity Assur. Ass'n v. Sims, 318 U.S. 608, 621 (1943).

99. Patent Cereals v. Flynn, 149 F.2d 711, 712 (2d Cir. 1945).

100. Int'l Bank of Miami v. Brock (In re Dania Corp.), 400 F.2d 833, 836-37 (5th Cir. 1968) (referencing 6 Collier ON BANkruptcy 625 (14th ed. 1965)).

101. In re Solar Mfg. Corp., 176 F.2d 493, 494-95 (3d Cir. 1949) (noting preplan sales are confined to emergency).

102. See Anderson \& Ma, supra note 4, at 3-5 (detailing criticisms).

103. See Lopucki \& Doherty, supra note 3. 
part of the reorganization plan, ${ }^{104}$ concluding that, after controlling for other variables, 363(b) sales are associated with lower sale prices than plan sales. ${ }^{105}$ The more recent conclusion is intuitively complementary to that from the 2007 study: both chronologically and characteristically, a plan sale is more proximate to a full reorganization than is a 363(b) sale.

The empirical evidence supports the approach taken in the courts and recommended by a large number of commenters of restricting access to 363 (b) sales in the absence of a "business justification." ${ }^{106}$ In Lionel Corp., the Second Circuit listed several factors relevant to finding business justification, which centered on questions of the declining asset value, fair valuation for the asset, and prejudice to remaining issues in the bankruptcy. ${ }^{107}$

One group of authors point out that the Lionel factors will be satisfied in a large percentage of cases. ${ }^{108}$ Consistent with that argument, a 2014 paper identifies a trend toward nearly $100 \%$ of bankruptcy business combinations' taking place under 363(b) rather than under a plan. ${ }^{109}$ Some version of the Lionel factors has been adopted in all the circuits that have reviewed Section 363(b) business combinations. ${ }^{110}$

\section{Regulatory Involvement in Plan Sales}

Bankruptcy business combinations conducted as part of the plan approval process are subject to more thorough regulatory review as well. Despite the automatic stay in bankruptcy, regulatory review of conduct by a bankrupt firm is permitted to "enforce . . . police and regulatory power ...."111 As the Bankruptcy Court for the District of New Jersey in TCI 2 Holdings recognized, both state and federal regulatory issues, including antitrust considerations, were relevant to the feasibility requirement for plan confirmation. The burden of proving feasibility is on the plan

104. See infra notes 111-14 and accompanying text.

105. Anderson \& Ma, supra note 4 , at $1,12,17,24-25$ tbl.5.

106. See Lionel Corp. v. Lionel Corp. (In re Lionel Corp.), 722 F.2d 1063, 1066 (2d Cir. 1983).

107. See id. at 1071; see also infra notes 122-26 and accompanying text.

108. Bodoh et al., supra note 78 , at 8-14.

109. Anderson \& Ma, supra note 4, at 8,18 tbl.1.

110. See, e.g., Stephens Indus. Inc. v. McClung, 789 F.2d 386, 390 (6th Cir. 1986); Institutional Creditors of Cont'l Air Lines, Inc. v. Cont'l Air Lines, Inc. (In re Cont'l Air Lines, Inc.), 780 F.2d 1223, 1226 (5th Cir. 1986); In re Summit Global Logistics, Inc., Nos. 08-11566, 08-11568, 08-11573, 08-11574, 08-11577, 08-11579, 08-11580, 08-11581, 08-11584, 08-11588, 08-11591，08-11593, 08-11595, 08-11597, 08-11599, 08-11600, 08-11601, 2008 WL 819934, at *9-14 (Bankr. D.N.J. Mar. 26, 2008); In re Med. Software Sol'ns, 286 B.R. 431, 440-41 (Bankr. D. Utah 2002); In re Delaware \& Hudson Ry. Co., 124 B.R. 169, 176 (Bankr. D. Del. 1991); In re Baldwin United Corp., 43 B.R. 888, 905-06 (Bankr. S.D. Ohio 1984).

111. 11 U.S.C. $\$ 362$ (b) (4); see, e.g., United States v. Air Fla., Inc., 48 B.R. 749 , 751 (S.D. Fla. 1984) (reversing bankruptcy court injunction of criminal antitrust proceedings). 
proponent, who must "demonstrat[e] that achieving the necessary [regulatory] approvals is not subject to 'material hurdles' or readily anticipated, significant obstacles." 112 Courts eschew the alternative approach that requires the relevant regulatory hurdles be surmounted before plan confirmation. ${ }^{113}$

The detailed solicitation and voting process and the feasibility requirement for confirmation work together to ensure that plan sales serve both stakeholder and non-stakeholder interests. Stakeholders have a voice in the process and an incentive to protect their interests. ${ }^{114}$ Non-stakeholders are protected by regulatory policy external to bankruptcy law, including antitrust, which bankruptcy courts must consult when deciding whether to confirm the plan. Finally, the frequent reality of dissenting stakeholders with incentives to prevent confirmation ensures regulators will be made aware of any potential for challenging its terms.

\section{a. Antitrust Premerger Review}

One such regulatory consideration is antitrust review of the business combination by the FTC or Department of Justice Antitrust Division. Under the Hart-Scott-Rodino Act, business combinations meeting certain dollar thresholds must be disclosed to the FTC and Antitrust Division before a transaction is consummated. ${ }^{115}$ Outside of bankruptcy, a reportable business combination may not be consummated until at least thirty days after reporting, permitting the FTC or Antitrust Division to investigate the transaction and the market to determine whether to bring a challenge. ${ }^{116}$ The statute also gives the investigating agency discretion to seek an additional thirty days for review of submissions made in response to a

112. In re Indianapolis Downs, LLC, 486 B.R. 286, 298-99 (Bankr. D. Del. 2013) (finding sale transaction likely to succeed because "necessary approvals are reasonably likely to be obtained"); In re Tribune Co., 464 B.R. 126, 184-85 (Bankr. D. Del. 2011) (holding that FCC approval of transfers of ownership interests to lenders did not prevent a finding of feasibility); In re WCI Cable, Inc., 282 B.R. 457, 487 (Bankr. D. Or. 2002) (explaining buyer had obtained regulatory approvals to acquire and to operate the business, therefore buyer had "waived any regulatory approval contingency"); cf. In re D \& G Invs. of W. Fla., Inc., 342 B.R. 882, 886 (Bankr. M.D. Fla. 2006) (finding no feasibility where zoning regulations prevented conduct necessary to reorganization plan); In re Cajun Elec. Power Coop., Inc., 230 B.R. 715, 747 (Bankr. M.D. La. 1999) (finding that regulatory risk was acceptable).

113. See Indianapolis Downs, 486 B.R. at 298 ("[C] ourts have not typically held up confirmation of a plan to wait for issuance of [regulatory] approvals.").

114. Creditors frequently use challenges for feasibility in efforts to prevent plan confirmations, including where plans involve sales or mergers of the debtor's business. See, e.g., In re River Capital Corp., 155 B.R. 382, 387 (Bankr. E.D. Va. 1991) (holding feasibility challenge unsuccessful).

115. 15 U.S.C. $§ 18 \mathrm{a}$ (2012); see 16 C.F.R. pts. 801-803 (2015). The reporting thresholds for 2014 are provided at 79 Fed. Reg. 3814 (Jan. 23, 2014).

116. 15 U.S.C. $\S 18 \mathrm{a}$ (b) (listing thirty-day waiting period). Challenges, when they occur, take the form of applications for temporary restraining orders followed by injunction proceedings. See, e.g., id. $\$ 53(\mathrm{~b})$. 
"second request" for documents or testimony. ${ }^{117}$ The Hart-Scott-Rodino Act is thus said to provide a "30+30-day" waiting period prior to consummation. In practice, because the parties to the combination must comply with the request for documents and testimony before the additional waiting period begins, the investigating agency frequently enjoys ninety days or longer to investigate and to prepare a challenge to the combination.

Plan sales do not alter the requirements of the Hart-Scott-Rodino Act. Compliance with regulatory requirements is essential to establishing that the plan is "feasible," or "not likely to be followed by the liquidation or the need for further financial reorganization of the debtor or any successor to the debtor under the plan."118 In practice, when a plan is confirmed that contains a business combination that exceeds the filing threshold, the parties to the combination must make a filing with the FTC and permit the waiting period to expire before consummating the transaction. This practical reality suggests that when a business combination presents antitrust concerns, it will be unlikely to succeed under a reorganization plan. The bankruptcy court will be concerned at the confirmation stage with both the certainty of at least sixty days' delay and the uncertainty regarding the outcome of the expected antitrust challenge. ${ }^{119}$

\section{b. Failing-Firm Defense}

A challenge to a plan sale is, like any full antitrust review of a business combination, subject to the failing-firm defense. Where the merging firms can demonstrate (1) imminent equity insolvency, (2) inability successfully to reorganize in Chapter 11, and (3) unsuccessful good-faith efforts to elicit reasonable alternative offers, that showing will favor the plan sale's being permitted to proceed. ${ }^{120}$ The fact of an extant Chapter 11 proceeding will facilitate, rather than undermine, the application of the failingfirm defense, because relevant evidence should exist with regard to the second element.

Likewise, under the feasibility standard for plan confirmation, the likely success of a proposed plan sale will require the bankruptcy court to evaluate the likely success of the failing-firm defense as part of its determination of the likely outcome of merger review. A bankruptcy court should be uniquely well-equipped to address the three elements of the defense. The financial affairs of the debtor, the likely success of reorganization in

117. 15 U.S.C. $\S 18 \mathrm{a}(\mathrm{e})$.

118. See 11 U.S.C. $\$ 1129$ (a) (11); see also In re TCI 2 Holdings, LLC, 428 B.R. 117, 148 (Bankr. D.N.J. 2010) (citing 11 U.S.C. § 1129(a) (11)).

119. Professor LoPucki suggests that feasibility concerns have taken a back seat to other considerations as part of bankruptcy courts' competition for large cases. Lopucki, supra note 42. Because Section 363(b) asset sales offer an alternative approach to business combinations that is more likely to evade regulatory review, courts need not risk plans' failure in order to accomplish debtors' desired business combinations. See infra notes 128-40 and accompanying text.

120. See supra notes 24-57 and accompanying text. 
the absence of the plan sale, and alternative purchasers for the debtor company are factual questions core to both the bankruptcy court's charge in a particular case and its general expertise. ${ }^{121}$

\section{Regulatory Involvement in "Other Than in the Ordinary Course of Business" Sales}

In contrast with plan sales, the speed, limited notice, and presumed emergency nature of a Section 363(b) sale undermine regulatory review of a business combination effected under that section. ${ }^{122}$ Notice to stakeholders of Section 363(b) sales is limited to twenty-one days "unless the court for cause shown shortens the time . . .."123 Because of Lionel-or comparable authority in a particular jurisdiction-the fact that a business combination is approved under 363(b) almost by definition suggests the court's determination that hasty resolution of the transaction is needed. ${ }^{124}$ Scholarship supports the proposition that courts regularly accept arguments that debtors in Chapter 11 may "melt like ice cubes."125 According to the leading empirical study of Section 363(b) sales conducted as part of a Chapter 11 proceeding, more than half of such business combinations that take place in large, public company bankruptcies are supported by an argument that the debtor's assets were wasting. ${ }^{126}$

I show below that opportunities for regulatory review of a 363(b) sale are also limited. ${ }^{127}$ Limited notice and opportunity for stakeholder involvement and limited opportunity for regulatory intervention, taken together, undermine the interests of both stakeholders and nonstakeholders.

121. Questions remain whether a bankruptcy court is appropriately incentivized to make these findings in the light of the policy underlying antitrust review of business combinations. For a discussion on those questions, see infra note 232 and accompanying text.

122. Some indication exists that experienced antitrust attorneys appreciate, and may take advantage of, this reality. See infra notes 135-40 and accompanying text (discussing SunGard/Comdisco merger and Comdisco Inc. bankruptcy). If that is so, the value of the Section 363 sale should increase as the regulatory risk from active merger enforcement increases. It would be an interesting exercise to study reliance on Section 363 to facilitate mergers during periods of active versus less-active federal merger enforcement-for example, the Bush Administration compared to the Obama Administration.

123. Fed. R. Bankr. P. 2002(a) (2). By default, objections must be made "not less than seven days before the date set for the proposed action," creating a fourteen-day or shorter period after receiving notice to make objection. Id. 6004(b).

124. Jacoby \& Janger, supra note 4, at 868 (“[T] he Lionel standard has evolved to provide a blueprint for hurry-up sale motions.").

125. See id. at 865 .

126. LoPucki \& Doherty, supra note 3, at 30-31.

127. See generally John D. Ayer, Michael Bernstein \& Jonathan Friedland, The Intersection of Chapter 11 and Antitrust, 25 Am. Bankr. InSt. J., Sept. 2006, at 18 (discussing merger review process when target entity is in bankruptcy). 


\section{a. Antitrust Review}

Section 363(b)'s text and amendment history provide evidence that Congress contemplated a need for speedy resolution to these "other than in the ordinary course of business" business combinations. ${ }^{128}$ Recognizing the possibility that premerger notification may be required under the Hart-Scott-Rodino Act, Congress amended Section 363(b) in 1984 and 1994, adding waiting periods for antitrust review by the FTC or Antitrust Division. ${ }^{129}$ The amendments provided for half of the usual waiting period before a transaction may be consummated-fifteen instead of thirty days-and allowed an extension up to ten days for further investigation, compared with the usual extension of thirty days. ${ }^{130}$ The foreshortened waiting period for antitrust review applicable to Section 363(b) business combinations mirrors the shorter waiting period for transactions in the nature of cash tender offers governed by the Williams Act. ${ }^{131}$ Shorter waiting periods for antitrust review of transactions governed by the Williams Act are explained by that statute's sixty-day limit on firm offers. ${ }^{132}$

Antitrust concerns are most likely to arise where the purchaser in a business combination conducted under Section 363(b) is from within the debtor company's industry rather than financial firms or other non-industry speculators. Such an intra-industry business combination presents the

128. 11 U.S.C. $\$ 363$ (b) (2012).

129. Bankruptcy Reform Act of 1994, Pub. L. No. 103-394, § 109, 108 Stat. 4106 (1994); Bankruptcy Amendments and Federal Judgeship Act of 1984, Pub. L. No. 98-353, 98 Stat. 333, at $\S 442$ (b) (1984). Prior to the 1994 amendments, the only waiting period recognized by the Bankruptcy Code was a ten-day period after notification. Dispute arose as to whether that ten-day period was extendable by thirty days on the issuance of a second request. See generally Robert B. Greenbaum \& Alan J. Meese, Premerger Review and Bankruptcy: The Meaning of Section 363(b)(2), 8 Antitrust Mag., Fall 1993, at 35, 35-36 (describing dispute and favoring no-extendability position); Spears, supra note 5, at 20-21 (arguing extendability position). In the 1994 amendments, Congress split the difference, moving to an automatic fifteen-day waiting period that was extendable by an additional ten days on the issuance of a second request.

130. See 11 U.S.C. $§ 363$ (b) (2); 15 U.S.C. § 18a (e) (2) (2012); Bankruptcy Reform Act $\S 109$.

131. 15 U.S.C. 78n (d) (5); see 11 U.S.C. 363(b) (2) (B) (i).

132. Neither the Bankruptcy Code nor its amendments explains the reason for matching the Section 363(b) waiting periods to those for cash tender offers. Testimony before Congress during the consideration of the Hart-Scott-Rodino Act explains the shorter waiting periods for cash tender offers: "The offering company must, under the Williams Act, accept tendered stock within 60 days of tender, or risk [the offer's] withdrawal." Merger Oversight and H.R. 13131, Providing Premerger Notification and Stay Requirements: Hearings Before the Subcomm. on Monopolies E Commercial Law of the H. Comm. on the Judiciary, 94th Cong. 80 (1976) (testimony of Eleanor M. Fox, Esq., Simpson, Thacher \& Barttlet, N.Y.C. on behalf of the Am. Bar Assoc.). Consistent with Professor Fox's understanding in 1976, since 1968, Williams Act $\S 14(d)(5)$ has permitted a tender offer to be withdrawn "at any time after sixty days from the date of the original tender offer." 15 U.S.C. $§ 78 n$ (d) (5). See generally Arnold S. Jacobs, The Williams Act-Tender Offers and Stock AcCumulations $§ 4.19$ (2015 ed.) (Sec. Law Handbook Series) (discussing 1968 adoption and legislative history of Section 14(d)(5)). 
kind of competitive "overlap" that implicates the federal anti-merger laws. ${ }^{133}$ A substantial percentage of 363(b) sales meet that characteristic. According to two authors writing in 2007:

Our data confirm the[] intuition that companies from within the debtor's industry would be the most likely purchasers at bankruptcy sales. We found that two-thirds of buyers were "strategic" in that they planned to use the assets in conjunction with their own businesses; only one-third were "financial" investors seeking a profit on the purchase. ${ }^{134}$

In cases in which antitrust concerns do arise, intuition and anecdotal evidence suggest the shorter periods for antitrust review undermine agency challenge to the business combination. ${ }^{135}$ On the basis of antitrust concerns, the Department of Justice opposed SunGard's purchase of the assets of its competitor Comdisco Inc. through a Section 363(b) sale conducted under the control of the bankruptcy court in Chicago.

In an article published shortly after the SunGard/Comdisco transaction closed, counsel to SunGard recognized the value to the federal antitrust authorities of "sufficient time to conduct the review and evidencegathering that the staff feels is necessary to convince the decision-makers in the Agencies (and ultimately a court) that the merger should be enjoined." 136 Counsel described a strategy of a "time squeeze," "forc[ing] the agency to choose between having to file suit before it is ready and allowing the transaction to be consummated." ${ }^{37}$ And noting the truncated waiting periods applicable to the 363 (b) sale procedure, counsel continued: "the speed with which SunGard was able to complete its submission left the DOJ with less time to prepare for litigation." 138 Statements by the Antitrust Division support counsel's view as to the success of the time squeeze strategy:

The United States has conducted an accelerated review of this matter. An investigation was opened on August 18, 2001 and the parties submitted their Hart-Scott-Rodino filings three days later. The United States rapidly served subpoenas on the parties, conducted numerous interviews and reviewed hundreds of boxes of

133. See 15 U.S.C. $§ 18$; 2010 GuIDELINES, supra note 11, pt. $§ 2.1 .4$, at 3 (concern for loss of "[s] ubstantial [h] ead-to-head [c]ompetition").

134. LoPucki \& Doherty, supra note 3, at 29.

135. Conversations with experienced practitioners support the intuition that reduced preparation time will lead to reduced success in antitrust challenges.

136. Stephen M. Axinn, Merger Review and Litigation Involving the Acquisition of Bankrupt Companies, 16 Antitrust Mag., Summer 2002, at 74, 74.

137. Id.

138. Id. at 75 . 
documents. By way of comparison, a typical investigation of this complexity takes four to five months. ${ }^{139}$

The result in the SunGard/Comdisco business combination was an unsuccessful merger challenge that allowed the 363 (b) sale to proceed. ${ }^{140}$

\section{b. Failing-Firm Defense}

Antitrust review of a business combination effected under Section 363 (b) is subject to the failing-firm defense to the same extent as any other merger transaction. For one example, when Hercules Offshore, Inc. purchased Seahawk Drilling, Inc. in a Section 363(b) business combination, the parties asserted a failing-firm defense on the basis of Seahawk's financial distress. ${ }^{141}$ According to an article written by counsel representing the acquiring company, the failing-firm defense was the basis for the Department of Justice's decision to close the investigation without a challenge. ${ }^{142}$

In the 2011 Seahawk 363(b) sale, the Justice Department closed its investigation and "early termination" was granted on March 30th, permitting the parties to consummate the transaction. ${ }^{143}$ The bankruptcy court approved the 363(b) sale on April 5th. ${ }^{144}$ The bankruptcy court was re-

139. United States' Redacted Memorandum of Law in Support of Motion for Temporary Restraining Order at 4, United States v. SunGard Data Sys., Inc., No. 01-2196 (D.D.C. Oct. 22, 2001).

140. United States v. SunGard Data Sys., Inc., 172 F. Supp. 2d 172, 193 (D.D.C. 2001) (denying request for injunction).

141. Fina \& Mehtal, supra note 44, at 3-4. See generally Hercules Offshore Buying Seahawk's Assets, Hous. Chron., Feb. 12, 2011, http://www.chron.com/business/ energy/article/Hercules-Offshore-buying-Seahawk-s-assets-1693118.php [http:// perma.cc/9J7S-ZLYZ] (describing agreement, bankruptcy filing, and cause for Seahawk's financial difficulty).

142. Fina \& Mehta, supra note 44, at 3-4. The Hercules/Seahawk transaction received an early termination, which means the investigation was closed and the merger was permitted to proceed before the waiting period expired. See Fed. Trade Comm'n, Notice of Early Termination, Trans. No. 20110627 (Mar. 30, 2011) [hereinafter Notice of Early Termination], available at http://www.ftc.gov/ enforcement/premerger-notification-program/early-termination-notices/2011per ma.cc06perma.cc27 [http://perma.cc/6GYB-X4VN]. See generally About Early Termination Notices, Fed. TRADE Comm'N, http://www.ftc.gov/enforcement/premerger-notification-program/early-termination-notices/about-early-terminationnotices [https://perma.cc/XU7S-EGYF] (last visited Nov. 20, 2015). From announcement to closing, the Hercules/Seahawk business combination required approximately two- and one-half months. See Hercules Offshore, Inc., Quarterly Report (Form 10-Q), at 7, 10 (Apr. 29, 2011); Hercules Offshore, Inc., Current Report (Form 8-K), at 2 (Apr. 27, 2011); Hercules Offshore, Inc., Current Report (Form 8-K), at 2 (Apr. 5, 2011); Hercules Offshore, Inc., Current Report (Form 8$\mathrm{K})$, at 2 (Feb. 11, 2011).

143. See Notice of Early Termination, supra note 142; see also Hercules Offshore, Inc., Current Report (Form 8-K), at 2 (Mar. 31, 2011) (describing the early termination and the legal basis for the business combination).

144. See Hercules Offshore, Inc., Current Report (Form 8-K), at 2 (Apr. 5, 2011) (describing bankruptcy court approval and transaction). 
lieved of any need to investigate the likely success of the defense by the early termination of the antitrust investigation.

The timeline of the Hercules/Seahawk transaction demonstrates a practical distinction between a business combination effected by a plan sale versus a 363(b) sale. In the first instance, the bankruptcy court will confirm the plan on the basis of an evaluation of the likelihood of the success in as-yet-unfinished regulatory review. In the second instance, the bankruptcy court will await the outcome of regulatory review before approving the sale. In the example case of the Hercules/Seahawk Drilling business combination, the bankruptcy court order approving the sale motion did not address the regulatory issues except to observe the provision of notice to "the state and federal units." 145

The early termination ${ }^{146}$ of the antitrust merger review successfully sought in the Hercules/Seahawk transaction is a common feature of 363(b) sales. Cross-referencing the FTC's database of early termination notices ${ }^{147}$ with the UCLA Bankruptcy Research Database ${ }^{148}$ shows that in a sizable percentage of business combinations effected under 363(b), the parties achieve early termination. ${ }^{149}$ Those include business combinations conducted in the context of large and politically salient bankruptcies, such as Lehman Brothers, Adelphia Communications, and Enron Corp., which one might expect in the ordinary course to draw some degree of premerger investigation, if only as a matter of the optics of tooeasily allowing mergers in high-profile industries. ${ }^{150}$ Details of those investigations, apart from the fact of early termination, are not made public, but in cases like Lehman Brothers, Enron, and Adelphia Communications, it is likely the antitrust enforcement agencies were motivated by failing-firm arguments.

145. Findings of Fact and Conclusions of Law on Debtors' Emergency Motion at 2 II 3, In re Seahawk Drilling, Inc., No. 11-20089 (Bankr. S.D. Tex. Apr. 5, 2011).

146. Colloquially called "ET"s.

147. Early Termination Notices, Fed. Trade Comm'n, http://www.ftc.gov/enforcement/premerger-notification-program/early-termination-notices [https:// perma.cc/6PCL-ZYMJ] (last visited Nov. 20, 2015). Search conducted for "debtor" produced early termination notices where one party (in all observed instances the acquired party) was a debtor-in-possession in a bankruptcy reorganization proceeding under Chapter 11.

148. Company Profile, UCLA-LoPucki Bankr. Research Database, http:// lopucki.law.ucla.edu/corporations.asp [http://perma.cc/KXD5-9CLW] (last visited Nov. 20, 2015) (listing all filed bankruptcies in data).

149. 36 FTC \& U.S. Dep't of Justice, Hart-Scott-Rodino Ann. Rep. (2013) [hereinafter HSR ANNUAL RePORT], available at https://www.ftc.gov/system/files/ documents/reports/36th-report-fy2013/140521hsrreport.pdf [https://perma.cc/ 4NAL-3MJ4]. The lion's share of all merger investigations in a given year is resolved through early termination. For example, in 2013, early termination was granted in a total of 797 of 1326 business combinations for which filings were received. Id.

150. Compare Early Termination Notices, supra note 147, with Company Profile, supra note 148 . 
The chronology of events for a business combination effected under Section 363(b) raises a question whether the failing-firm defense is appropriate in any instance for such a transaction. The defense requires a demonstration that the bankrupt firm "would not be able to reorganize successfully under Chapter $11 \ldots$..."151 The nature of a Section 363(b) sale is that the bankrupt debtor does not attempt to reorganize its business in Chapter 11. Instead, the debtor files Chapter 11 with the intention of selling the company. For one representative example, Seahawk Drilling stated to the bankruptcy court in 2011, it "filed these Chapter 11 bankruptcy cases to effectuate the terms and provisions of the [asset purchase agreement]."152

\section{Non-Reportable Transactions}

Some transactions raising antitrust concerns are not subject to mandatory reporting and waiting periods for federal agency review before they are consummated. ${ }^{153}$ Several tests for reportability exist, all turning in some manner on the size (in terms of dollar values) of the parties or the size of the transaction. ${ }^{154}$ An example is the sale of Gulf States Steel assets in a 363(b) sale conducted as part of Chapter 7 liquidation proceedings. ${ }^{155}$ Although an unsuccessful bidder raised the specter of antitrust concerns based on the involvement of a dominant competitor in the winning-bidder consortium, the antitrust enforcement agencies did not review the $\$ 6.3$ million transaction. ${ }^{156}$

Whether those non-reportable business combinations occur in or out of bankruptcy, they may be concluded before agencies have the opportunity to review and if appropriate move to block them. Remedying consummated mergers presents a unique challenge referred to as "unscrambling of the eggs," 157 a colorful expression invoking the challenges of recreating competition once assets and operations have been combined and competi-

151. 2010 Guidelines, supra note 11, pt. 11, at 43.

152. Debtors' Emergency Motion at 7 II 12, In re Seahawk Drilling, Inc., No. 11-20089 (Bankr. S.D. Tex. Feb. 12, 2011). Evidence suggests this is more common than rare. See generally LoPucki, supra note 42, at 168-69 (acknowledging that, in many cases, 363 sales are reason for bankruptcy filing).

153. See 16 C.F.R. pts. 801-803 (2015).

154. Revised Jurisdictional Thresholds for Section 7A of the Clayton Act, 79 Fed. Reg. 3814 (Jan. 23, 2014) (establishing updated reporting thresholds).

155. See In re Gulf States Steel, Inc., 285 B.R. 497, 504 (Bankr. N.D. Ala. 2002) (noting transaction valued at $\$ 6.3$ million).

156. See id. at 504 n.1 (antitrust concerns raised); see also Nancy C. Dreher, Eleventh Circuit Rules That Sale Free and Clear in Bankruptcy Does Not Foreclose Later Antitrust Action by Unsuccessful Bidder, Bankr. Serv. Current Awareness Alert, Dec. 2006, at 1, 1 (Thomson Reuters, Westlaw Next) ("The group then contacted the Federal Trade Commission, which did nothing.").

157. Guide to Antitrust Laws: Mergers, Fed. Trade Comm'n, http://www.ftc.gov/ tips-advice/competition-guidance/guide-antitrust-laws/mergers [https://perma .cc/7UPS-K667] (last visited Nov. 19, 2015) (internal quotation marks omitted). 
tively sensitive information has been exchanged. ${ }^{158}$ The result is that, except in rare cases, a consummated business combination cannot meaningfully be remedied. ${ }^{159}$

Intuition suggests the more substantial proceedings involved in achieving bankruptcy court approval of a plan sale ${ }^{160}$ renders non-reportable business combinations more likely to come to the advance attention of the enforcement agencies. For example, dissenting creditors might find alerting the antitrust authorities to the proposed business combination to be a profitable strategy to undermine the plan. In contrast, rapid business combinations conducted under Section 363(b), conducted without meaningful creditor involvement, and perhaps even with a lack of meaningful court review, ${ }^{161}$ are more likely to escape the notice of the enforcement agencies.

\section{Conflicting Schemes}

Part II explained the legal and regulatory framework for the treatment of merger claims in and out of bankruptcy. In Part III, this Article demonstrates how those rules and procedures create conflicts in which antitrust goals are subordinated to bankruptcy policies favoring the constituents of the estate.

A common result of business bankruptcies is the sale of the firm in bankruptcy. ${ }^{162}$ Increasingly commentators observe that the sale of the

158. As an indication of the challenges inherent in this process, the Department of Justice criminally prosecutes "gun-jumping," or proceeding with a merger transaction before the Hart-Scott-Rodino waiting periods have expired. See generally Richard Liebeskind, Speech at ABA Annual Meeting: Gun-Jumping: Antitrust Issues Before Closing the Merger (Aug. 8, 2003), available at http:/ /www.pillsburylaw.com/siteFiles/Publications/16ADC9E2C53CF6E9F97E3F0A3F6F3242.pdf [http://perma.cc/5RBG-ZQHW].

159. See Guide to the Antitrust Laws: Mergers, supra note 157 ("The premerger notification requirements of the Hart-Scott-Rodino Act allow the antitrust agencies to examine the likely effects of proposed mergers before they take place. This advance notice avoids the difficult and potentially ineffective "unscrambling of the eggs' once an anticompetitive merger has been completed.”). The unscramblingof-the-eggs concern is less likely to arise in a pure acquisition as opposed to a merger context. In Gulf States, the winning consortium later sold the assets for a substantial profit. See Dreher, supra note 156, at 1 . Such a remarketing demonstrates the business operations of the bankrupt debtor were never meaningfully combined with the purchaser, and an antitrust challenge could have remedied an illegal merger (had it been found to occur).

160. See supra notes $150-56$ and accompanying text.

161. See supra notes $42,92-96$ and accompanying text.

162. According to the UCLA-LoPucki Bankruptcy Research Database, over the decade from $2004-2013,17 \%$ to $42 \%$ of all large public company bankruptcies disposed of each year were concluded with a Section 363(b) sale of all or substantially all assets. See UCla-LoPucki Bankr. Research Database, 363 Sales of All or Substantially All Assets in Large, Public Company Bankruptcies, as a Percentage of All Cases Disposed, by Year of Case Disposition, available at http:/ / lopucki.law.ucla.edu/tables_and_graphs/363_sale_percentage.pdf [http://perma .cc/UK98-F646]. 
firm may be the purpose of the bankruptcy filing. ${ }^{163}$ Prominent defenders of that result argue that bankruptcy sales move assets to their highest value use, ${ }^{164}$ while leading critics argue that Section 363 (b) sales of an entire firm benefit purchasers and insiders to the prejudice of diffuse stakeholders. ${ }^{165}$ Existing commentary ignores the question treated in this Article: the impacts of sales of firms in bankruptcy on non-stakeholders (like consumers) or on external regulatory policy (including antitrust). ${ }^{166}$

\section{A. Bankruptcy Business Combinations Are Intended to Maximize Value for Investor Interests}

"The purpose of a $\S 363$ (b) sale is to maximize the benefit to the debtor's entire estate." 167 Commentators agree. In spite of their conflicting arguments and conclusions, leading theorists and empirical scholars studying 363(b) sales start from the same initial premise that the bankruptcy reorganization process is intended to maximize the value of the firm's assets. "In the same spirit," as Ronald Coase's baseline premise in The Nature of the Firm, ${ }^{168}$ two commentators writing in the law-and-economics tradition contended in 2002 that bankruptcy "reorganization law ought to begin by ascertaining the value of keeping particular assets together inside a given firm." ${ }^{169}$ Their conclusion that bankruptcy asset sales are appropriate substitutes for reorganizations relies on the premise that in the modern economy, most assets are not firm specific, so value may be maximized by bankruptcy asset sales. ${ }^{170}$ Dissenters from that view nonetheless also see the core goal of Chapter 11 as maximizing estate value. ${ }^{171}$ They observe with regard to judicial supervision of bankruptcy sales, "[b]ankruptcy law charges bankruptcy judges with the responsibility to prevent inadequate-price sales." 172

163. See LoPucki, supra note 42, at 169 (citing TWA bankruptcy as lead example); Baird \& Rasmussen, supra note 2, at 751 (same).

164. Baird \& Rasmussen, supra note 2, at 751, 756, 786-88; see also JACKsON, supra note 10, at 219, 223.

165. See LoPucki \& Doherty, supra note 3, at 10 (reporting empirical result that Section 363(b) sales produce depressed value for assets). Anderson \& Ma recently showed that LoPucki and Doherty's empirical result was limited to 363(b) sales rather than plan sales. Anderson \& Ma, supra note 4, at 1.

166. Other external regulatory policies exist as well. For example, the FCC has become involved in review of bankruptcy asset sales that implicated broadcast license ownership regulations. See Ilene Knable Gotts, Nathaniel L. Asker \& Jack N. Goodman, US Antitrust and FCC Treatment of Acquisitions of Distressed Communications Businesses, 6 Competition L. InT'L, Apr. 2010, at 11, 14-15.

167. In re Trans World Airlines, Inc., No. 01-00056(PJW), 2001 WL 1820326, at *11 (Bankr. D. Del. Apr. 2, 2001).

168. See R.H. Coase, The Nature of the Firm, 4 Economica 386, 390-92 (1937).

169. Baird \& Rasmussen, supra note 2, at 758.

170. See id. at 786 .

171. See LoPucki \& Doherty, supra note 3 , at 3.

172. Id. at 4 . 
Bankruptcy is lauded for facilitating these transactions and thereby preserving the going concern value of the enterprises. The asserted benefits are two-fold: first, by selling a bankrupt firm as a going concern, a bankruptcy court maximizes the value of the firm. As a going concern, the firm was worth the discounted value of expected future profits. In liquidation, the asset value is limited to the aggregate of tangible and semi-tangible inputs, which have limited viable alternative uses. The valuemaximizing result is good for investors in the firm, a class that includes creditors, employees, equity investors, contracting partners, and the communities in which the firm's facilities are located.

Second, by selling the firm as a going concern, the broader economy benefits through the maintenance of a productive business. In the absence of a bankruptcy sale, the firm may have ceased operations. ${ }^{173} \mathrm{Had}$ that occurred, the firm would not be manufacturing widgets; people would not be employed in running the business; contracting partners and communities would be impacted; creditors would go unpaid; and the assets that went into the organization would be dissipated to the four winds, possibly redeployed to lower value uses. The same two-part justification holds for any business combination transaction in which one firm's failure is a realistic consequence of the transaction's failure, including some percentage of business combinations conducted under protection of the bankruptcy court. ${ }^{174}$

\section{B. Bankruptcy Business Combinations May Present Antitrust Concerns}

Antitrust law's anti-merger provision, Clayton Act Section 7, ${ }^{175}$ is also implicated by these business combination transactions. Before combining in 2014, US Airways and American Airlines were two of five remaining major domestic air carriers operating in an industry with oligopoly characteristics, including price leadership and demonstrated limited willingness

173. Evidence points to the contrary, which may explain why American and US Airways did not assert a failing-firm defense to the Justice Department's complaint to block the merger. See Defendant AMR Corporation's Answer (and Affirmative Defense) to Plaintiff's Amended Complaint, United States v. US Airways Grp., Inc., 979 F. Supp. 2d 33 (D.D.C. 2013) (No. 1:13-cv-1236 (CKK)), 2013 WL 5376689.

174. See, e.g., In re Trans-World Airlines, $2001 \mathrm{WL} 1820326$, at *14 (Bankr. D. Del. Apr. 2, 2001).

$[\mathrm{T}]$ here is a substantial public interest in preserving the value of TWA as a going concern and facilitating a smooth sale of substantially all of TWA's assets to American. This includes the preservation of jobs for TWA's 20,000 employees, the economic benefits the continued presence of a major air carrier brings to the St. Louis region, and preserving consumer confidence in purchased TWA tickets American will assume under the sale.

Id.

175. See 15 U.S.C. $\$ 18$ (2012) (rendering illegal mergers or asset sales that would "tend to create a monopoly"). 
to compete head-to-head in city-pair routes. ${ }^{176}$ The merger presented substantial competitive concerns. ${ }^{177}$ The level of consolidation in the airline industry in the wake of that merger is sufficiently great that it can be expected to be functionally irreversible in the absence of dramatic industry shake-up. ${ }^{178}$

American Airlines' purchase of bankrupt Trans-World Airlines in 2001 was, on its face, likewise a matter of competitive concern. Both American and TWA were nationwide legacy carriers with route systems concentrated around Midwestern US hubs (St. Louis for TWA, Chicago for American) and with significant trans-Atlantic presences. ${ }^{179}$ Statements entered into the record at a February 2001 Senate Hearing on airline consolidation noted substantial concerns for increasing consolidation in the airline industry. ${ }^{180}$ According to testimony entered into the record by the General Accounting Office, on some metrics the American-TWA business combination presented greater concerns than did proposed (non-bankruptcy) business combinations of airlines including United/US Airways and Northwest/Continental Airlines, both of which failed after Justice Department opposition. ${ }^{181}$ TWA entered bankruptcy specifically to facilitate a business combination that had been planned in advance of TWA's filing. ${ }^{182}$

176. See Complaint at 3, US Airways, 979 F. Supp. 2d 33 (D.D.C. 2013) (No. $1: 13-\mathrm{cv}-1236)$.

177. See HSR Annual Report, supra note 149, at 12 ("The complaint alleged that the transaction, as originally proposed, would substantially lessen competition for commercial air travel and result in passengers paying higher airfares and receiving reduced service. In addition, the transaction would reduce competition in the market for slots at National Airport where the merged carrier would control almost $70 \%$ of the slots.").

178. See Danielle Kurtzleben, Regulators Sue to Stop American Airlines-US Airways Merger, but Why Now?, U.S. News (Aug. 13, 2013), http://www.usnews.com/news/ articles/2013/08/13/regulators-sue-to-stop-american-airlines-us-airways-mergerbut-why-now [http://perma.cc/34GP-KWMY] ("My instinct is we're reaching that tipping point ..... When you get down to four airlines that effectively own air service in the U.S., these players are too big for any new entrants to come in and be a serious competitive threat going forward." (internal quotation marks omitted)). It is difficult to imagine what changes might suffice, but technological innovations comparable to the Internet replacing home operating systems as consumers' primary means of electronic interface may be required.

179. See Effects of American Airlines/TWA Transaction Hearing, supra note 58.

180. See id. Most of the comments favored the merger because of concerns for lost economic value and jobs and other effects of liquidation, although a few found the concerns for consolidation to exceed the harms from liquidation.

181. See id. at 44 (statement of JayEtta Z. Hecker, Dir., Physical Infrastructure Issues, U.S. Gen. Accounting Office); J. Bruce McDonald, Deputy Assistant Att'y Gen., U.S. Dep't of Justice, Antitrust Div., Remarks Before the Regional Airline Association President's Council Meeting: Antitrust for Airlines 6-7 (Nov. 3, 2005), available at http://www.justice.gov/atr/speech/antitrust-airlines [http://perma .cc/4MGU-45FN]. See also generally Joel G. Chefitz, A Tale of Two Mergers: American/ TWA and United/USAir, 14 DePaul Bus. L.J. 215, 215-16 (2002).

182. See LoPucki, supra note 42, at 169. 
SunGard's purchase of Comdisco was a business combination taking a three-firm market to a duopoly in a market for "shared hotsite disaster recovery services for large scale enterprise computer processing centers," 183 with the combined company expected to control $71 \%$ of the market. ${ }^{184}$ The Justice Department further alleged that SunGard and Comdisco were "viewed as the two closest, and sometimes the only, bidders ...."185 An already concentrated market became a duopoly over a lawsuit by the Justice Department seeking injunctive relief. The bankruptcy business combination was approved although Hewlett Packard Corp. was a competing bidder for the bankrupt Comdisco, Inc. ${ }^{186} \mathrm{Had}$ Hewlett-Packard purchased the assets, the competitive concerns would largely have been obviated. ${ }^{187}$

Financial News Network's (FNN) 1992 sale to General Electric, the parent company of CNBC, was a merger bringing a two-firm market to a monopoly. At the time the two were the only 24-hour financial news broadcasters-FNN had pioneered the now-common concept of news with a stock ticker across the bottom of the screen. Such mergers to substantial concentration threaten consumer harm as the surviving firms gain the power to control prices, quality, choice, and the level of output.

Bankruptcy sales can be expected to occur most frequently where competitive overlaps exist. A sale of a company that must be conducted quickly is most likely to attract buyers with expertise in the relevant industry because of their information advantage. ${ }^{188}$ If an effort is made to maximize the value received at the sale, buyers that stand to gain from synergies between the business of the bankrupt debtor and their own business will place a premium on the company for that reason. Likewise, buyers who anticipate acquiring market power by combining the bankrupt debtor's capacity and market share with their own will place a premium on the company for that reason.

183. See Redacted Complaint, United States v. SunGard Data Sys., Inc., 172 F. Supp. 2d 172 (D.D.C. 2001) (No. 01-2196), available at http://www.justice.gov/ atr/case-document/sungard-data-2-9384 [http://perma.cc/B7A3-M9RZ].

184. See United States v. SunGard Data Sys. Inc., 172 F. Supp. 2d 172 (D.D.C. 2001); Redacted Complaint, supra note 183, at 10-11.

185. Redacted Complaint, supra note 183, at 11-12.

186. See Company News; Comdisco Agrees to Sell Unit to Hewlett Packard, N.Y. Times, Oct. 31, 2001, http://www.nytimes.com/2001/10/31/business/companynews-comdisco-agrees-to-sell-unit-to-hewlett-packard.html [http://perma.cc/ TK6K-LNBN].

187. See United States' Memorandum of Law in Support of its Motion for a Temporary Restraining Order at 25 \& n.62, United States v. SunGard Data Sys., Inc., No. 01-2196 (D.D.C. Oct. 22, 2001) (describing Hewlett Packard as a "fringe competitor" currently unable to serve large customers), available at http://www .justice.gov/atr/case-document/sungarddataredactedmemorandum\#N_62_.

[https:/ / perma.cc/T5M4-63G9?type=image].

188. Out-of-industry buyers will need to bear time and cost to compete in the bidding process. 
The theory is supported by empirical evidence. In a 2007 study of 363(b) sales, two authors found that "data confirm their intuition that companies from within the debtor's industry would be the most likely purchasers at bankruptcy sales. We found that two-thirds of buyers were 'strategic' in that they planned to use the assets in conjunction with their own businesses . . .."189

\section{Categorizing Conflict Cases}

In analyzing the conflict between bankruptcy law's reorganization objectives and antitrust law's competition concerns, it is useful to categorize business combination transactions in which both issues are present. In one category of cases, the reorganization objectives can be accomplished without prejudice to competition concerns through a business combination with a competing bidder. In a second category of cases, reorganization objectives can be accomplished without any business combination's taking place. In a third category of cases, reorganization objectives can only be achieved through a business combination transaction. It is only in this third category that the tension between bankruptcy and antitrust may be irreconcilable. The third category also implicates the antitrust law failing-firm defense.

\section{Competing Bidders}

Cases exist in which the business combination that took place was unnecessary to accomplish the economic goals of the bankruptcy reorganization. A competing bid may have presented lesser competitive concerns. Hewlett Packard challenged the bankruptcy court's approval of the SunGard-Comdisco merger because it would have liked to purchase Comdisco in order to enter the market as a competitor, preserving the pre-combination level of competition while also ensuring the assets remained in the market. Dow Jones and Westinghouse fought the CNBC-FNN merger because those firms would have liked to buy the Financial News Network.

These cases demonstrate the conflict between bankruptcy and antitrust, because the bankruptcy court sought the strongest of the available bids, even where those strongest bids presented greater competitive concerns. Bankruptcy courts have limited incentive to consider the less anticompetitive alternative transaction. ${ }^{190}$

189. LoPucki \& Doherty, supra note 3 , at 28-29. This phenomenon has been observed historically as well. See $i d$. at 12 (noting similar conclusion from study using data from 1980s).

190. One counterintuitive result of the LoPucki/Doherty study might be that a slower sale process would serve both the interests of bankruptcy and those of antitrust better than a fire-sale approach. A longer shopping period for the bankrupt debtor might engage the antitrust enforcement agencies earlier; might enable purchasers who present lesser competitive concerns to evaluate and participate in the bidding; and might diminish management preference for 363(b) sales over plan sales, causing more business combinations to take place through the antitrustdeferential plan sale process. At the same time, LoPucki and Doherty's work, to- 


\section{No Business Combination Necessary}

A business combination may be unnecessary to preserve the bankrupt firm's assets in the marketplace. American Airlines had successfully reorganized in Chapter 11, returning to profitability, before the bankruptcy court approved the US Airways business combination. This category might frequently involve a firm that reaches an agreement to enter a business combination transaction and files bankruptcy to facilitate the combination. ${ }^{191}$

According to one empirical study, this category is implicated in a fair number of 363(b) sales. ${ }^{192}$ These authors analyzed thirty 363 (b) sale transactions and concluded that the value produced in those fire sales was substantially less than the value produced by a Chapter 11 reorganization. ${ }^{193}$ A possible corollary of that conclusion is that in a fair number of 363(b) sales, the fire sale was not necessary to effectuate the value-maximizing purposes of bankruptcy; a plan sale or a full reorganization might have been a superior approach. ${ }^{194}$

\section{Irreconcilable Conflict: Anticompetitive Combination Essential to Reorganization}

In other cases, some form of asset sale or merger conducted under a bankruptcy court's supervision may be necessary to preserve the value of the firm. It is unlikely that TWA could have emerged from its 2001 bankruptcy filing to provide air passenger service as a free-standing firm. ${ }^{195}$ As the bankruptcy court found, "In TWA's case, a sale pursuant to $\S 363$ is the only viable alternative for preserving and capturing the enterprise

gether with Anderson and Ma's recent article, suggest the goals of estate value maximization would be better accomplished under such an approach.

191. Filing to facilitate the business combination is not always an indication that the business combination is unnecessary to preserving value. For example, in the American Airlines/Trans-World Airlines business combination and that of Seahawk Drilling, Inc. and Hercules Offshore, Inc., both were true failing-firm stories, but both also involved a bankruptcy filing specifically intended to facilitate the business combination. See supra notes 141-82 and accompanying text; see also, e.g., Fina \& Mehta, supra note 44, at 4 (describing Hercules/Seahawk business combination undertaken as asset sale under Bankruptcy Code Section 363(b) after filing bankruptcy (citing In re Seahawk Drilling, Inc., No. 11-20089 (Bankr. S.D. Tex. Feb. 12, 2011))). See generally LoPucki, supra note 42, at 167-80 (describing forum shopping to facilitate approval of business combinations under Section 363).

192. See LoPucki \& Doherty, supra note 3.

193. See id.

194. Anderson and Ma followed up LoPucki and Doherty's study by comparing the results of 363(b) sales with those of plan sales, finding that plan sales return substantially more to the stakeholders than do 363(b) sales. See Anderson \& Ma, supra note 4 . That conclusion suggests that both a later sale and a reorganization are viable alternatives to many $363(\mathrm{~b})$ sales.

195. Effects of American Airlines/TWA Transaction Hearing, supra note 58 (testimony of Michael E. Levine, Adjunct Professor of Law, Harvard Law Sch.) ("I do not think [the American/TWA business combination] eliminates competition in a meaningful way because I think TWA is, in fact, a failing company."). 
value of TWA's assets."196 Evidence suggests no suitors were realistically available other than American. ${ }^{197}$ In general, transactions in this third category include those in which both (1) no other bidder is available and (2) a sale of the bankrupt firm is the only possibility for maintaining the assets operating in the market of concern.

Transactions with these characteristics satisfy both bankruptcy goals, which seek to maximize estate value, and antitrust goals, which seek to preserve assets in the market rather than to permit the value lost by out-ofmarket liquidation proceedings. These transactions should be permitted whether pursued during bankruptcy or outside of bankruptcy.

Cases in this third category should, in every instance, satisfy the antitrust law failing-firm defense. By definition, reorganization in Chapter 11 is not possible; alternative purchasers presenting lesser competitive concerns are not available; and the firm is facing imminent insolvency. ${ }^{198}$ In the case of the American Airlines/TWA merger, the Justice Department granted early termination of the merger investigation. ${ }^{199}$

\section{Why Anticompetitive Business Combinations Succeed in Bankruptcy}

The prior sub-part identified three categories of bankruptcy business combinations defined by the level of antitrust concern presented. Theory suggests cases in which the substantive standards of bankruptcy and of antitrust conflict will not be rare but will arise in the normal course. It is precisely that which makes bankruptcy business combinations attractive to bankruptcy estate constituents that also renders them problematic as a matter of competition policy. When a company or asset is put up for bid, its most significant competitor should be the highest bidder.

196. In re Trans World Airlines Inc., No. 01-00056(PJW), 2001 WL 1820326, at *12, *14 (Bankr. D. Del. Apr. 2, 2001) ("Given TWA's precarious financial history, I found that a rejection or denial of the Sale Motion would have resulted in an immediate and precipitous decline in the financial affairs of TWA with a very high probability, if not certainty, of liquidation. A liquidation would result in material adverse harm to TWA's diverse creditor constituencies and loss of enterprise value."); McDonald, supra note 181, at 9.

197. See Effects of American Airlines/TWA Transaction Hearing, supra note 58, at 26 (testimony of William F. Compton, President and CEO, Trans-World Airways) ("Only American Airlines saw fit this winter to come forward with a proposal that was not merely an offer to cherry-pick a prized asset here and a prized asset there. American proposed a comprehensive solution that will realize for our creditors the value of TWA as a going concern ....."). Other potential bidders, including Continental Airlines and a group including financier Carl Icahn, did not produce bids in compliance with the bidding procedures. See Trans World Airlines Inc., 2001 WL 1820326 , at $* 6-7$.

198. See 2010 Guidelines, supra note 11, pt. 11 (noting requirements for defense).

199. See 20011333: AMR Corporation; Trans World Airlines, Inc. (Debtor-in-Possession), Fed. Trade Comm'n, (Mar. 16, 2001), available at http://www.ftc.gov/enforcement/premerger-notification-program/early-termination-notices/20011333 [https://perma.cc/DFN6-6QBH?type=image] (granting early termination). 
There are two reasons for that expectation. First, the most significant competitor is experienced and established in the relevant market. It has the wherewithal to use the assets efficiently. Second, that competitor stands to realize a monopoly premium from the business combination. ${ }^{200}$ The combination either creates a position of market dominance with the attendant pricing power or it solidifies a position of dominance that it already had. Of those two reasons, the first may reflect synergies from the merger and may be beneficial, although nothing suggests that the synergies between the dominant competitor and the bankrupt firm are greater than synergies that less harmful business combinations might present. The second reason-pricing power from the combination-is purely harmful.

\section{Irreconcilable Goals}

Bankruptcy business combinations have, as one goal, the maximal value of the bankruptcy estate. Antitrust has the goal of preventing harm to consumers that results from dominance. Bankruptcy law's value maximization goal looks to effects on the investing interests in the bankrupt firm. The goal is effectuated, in part, through rapid consummation of transactions where wasting asset value is a concern. As a matter of bankruptcy policy, mergers or asset sales that produce supra-normal returns are desirable.

Antitrust looks to effects on the market other than the investor interests of the bankrupt firm. ${ }^{201}$ Antitrust goals depend on economic efficiency. Merger review under antitrust law is not concerned with rapid consummation of transactions, but rather with the accuracy of the agencies' and courts' evaluations of the net consequences of a transaction. ${ }^{202}$ Although neither the law nor public expressions of policy so indicate, observers understand that delay may be a deliberate strategy for merger enforcement. ${ }^{203}$

\section{Bankruptcy Procedures Undermine Antitrust Review}

Bankruptcy relies on a system of specialized non-Article III courts charged with maximizing the value of the debtor's assets for the benefit of the constituents of the bankruptcy estate. Bankruptcy courts are also con-

200. These same explanations exist when the failing-firm defense is applied outside of bankruptcy. See supra notes 26-27 and accompanying text.

201. Under some views of the role of antitrust in economic regulation, extramarket effects also are relevant.

202. The accuracy goal of antitrust is also reflected in the standards for merger review. Courts analyze mergers under the notoriously complex Rule of Reason rather than the more efficient but blunt instrument of per se illegality or legality.

203. For example, the grant of a preliminary injunction, though it does not literally forbid a merger in perpetuity, has that practical effect because the merging parties are not willing to wait or invest resources in fighting the case at a permanent injunction proceeding. 
stitutionally competent to hear matters "arising in" or "related to" those bankruptcy proceedings, although the extent of that competence is the subject of recurring dispute. ${ }^{204}$ Antitrust claims have been treated as within the bankruptcy court's jurisdiction in cases including Financial News Network, ${ }^{205}$ although constitutional challenges to bankruptcy court jurisdiction have not been litigated in the context of review of antitrust claims. Substantial questions exist whether bankruptcy courts, faced with specific incentives and limited experience, are institutionally capable of giving full attention to antitrust policy concerns. ${ }^{206}$

Under the Financial News Network rule, bankruptcy courts have jurisdiction to decide complex antitrust questions through a process of reference from United States district courts. ${ }^{207}$ That jurisdictional authority does not necessarily mean they must decide these issues. Procedures are available for district courts to "withdraw the reference" and require the bankruptcy court to abstain from deciding an issue, sending the matter to the district court for decision. ${ }^{208}$ No consistent rule for withdrawing the reference has emerged in the courts. Academic literature does not contain a theoretical argument supporting any bright-line rule.

The Bankruptcy Code and Hart-Scott-Rodino Act contain an abbreviated premerger notification process, shortening by one-half to fifteen days the period for initial government review of the proposed merger, and by two-thirds to ten days the subsequent waiting period after full compliance with a government request for further information, before consummation of the merger or asset sale. ${ }^{209}$ Those abbreviated waiting periods reflect a policy favoring quick resolution of proceedings to avoid wasting assets and

204. See, e.g., Stern v. Marshall, 131 S. Ct. 2594 (2011).

205. See In re Fin. News Network, Inc. 126 B.R. 157 (S.D.N.Y. 1991).

206. Those favoring less antitrust enforcement applaud that result. See, e.g., Greenbaum \& Meese, supra note 129, at 37 ("The [bankruptcy] court is more likely to possess the experience necessary to appreciate fully the exigencies of the situation. . . . to evaluate the antitrust issue most likely to predominate, the application of the failing firm defense.").

207. See 28 U.S.C. $\$ 158$ (2012); id. § $157(\mathrm{a})$.

208. See id. $\S 157(\mathrm{~d})$.

209. See 11 U.S.C. $\$ 363$ (b) (2) (2012). Enacted in 1976 as an amendment to the Clayton Act, the Hart-Scott-Rodino Act requires merging parties to give the federal antitrust enforcement agencies advance notice of an intended merger or asset sale that exceeds certain thresholds of economic relevance. See 15 U.S.C. $\S 18 \mathrm{a}$ (2012). The Bankruptcy Code originally did not include any reference to the requirement of pre-merger notification. See Act of November 6, 1978, Pub. L. No. 95-598, § 363(b), 92 Stat. 2549. Paragraph (b) (2) was added in 1984, including a ten-day waiting period after notification to the enforcement agencies, with no statutory waiting period after compliance with the second request. See Bankruptcy Amendments and Federal Judgeship, Pub. L. No. 98-353, § 442, 98 Stat. 333 (1984). This may be in part because Congressman Peter Rodino, one of the cosponsors of the Hart-Scott-Rodino Act, was Chairman of the House Judiciary Committee in 1984. See Peter W. Rodino, WikipediA, http://en.wikipedia.org/wiki/Peter_W._Rodino [http://perma.cc/7P6Q-BN8R] (last modified Oct. 13, 2015). In 1994, Section 363(b) (2) was amended to include the double waiting period-fifteen days prior to second request, ten days after substantial compliance-that cur- 
to ensure creditors are compensated. They are likely insufficient for full merger review and are also insufficient to permit enforcers to adequately prepare for litigation to block the merger or asset sale. Sophisticated firms understand that the bankruptcy forum is preferable for bringing about a successful merger over government opposition.

Neither the legislative history of the Bankruptcy Code nor the academic literature justifies foreshortened procedures in bankruptcy. Commentators favoring bankruptcy or antitrust acknowledge competing justifications for their preferred approaches. On one hand, bankruptcy involves a "need for speed," supporting foreshortened waiting periods. On the other hand, serious antitrust review takes time, supporting longer waiting periods. ${ }^{210}$

\section{Antitrust Agency Review of Business Combination Transactions Under Section 363(b)}

Section 363(b) explicitly recognizes the need for federal antitrust review of mergers or asset sales beyond a certain minimum size, as has been dictated by the Hart-Scott-Rodino (HSR) Act since $1976 .{ }^{211}$ This section requires notice to the appropriate agencies for a "reportable transaction" for which notice would be required outside of bankruptcy, determined by the size of the parties, size of the assets, or value of the securities involved in the transaction. ${ }^{212}$

Since amendments to the section in 1994, Section 363(b) has incorporated waiting periods to allow for agency review of the proposed transaction. ${ }^{213}$ HSR waiting periods for bankruptcy sales or mergers are truncated relative to the non-bankruptcy review periods in the HSR Act. Outside of bankruptcy the initial waiting period is thirty days, followed by an additional thirty days after party compliance with a so-called second request for documents and testimony regarding the transaction. ${ }^{214}$ In an asset sale or merger conducted in bankruptcy under Section 363(b), the initial waiting period is fifteen days and the period after a second request is ten days, identical to the waiting periods for a cash tender offer. ${ }^{215}$

rently exists. See Act of August 19, 1974, Pub. L. No. 93-394, § 109, 88 Stat. 792 (referencing 15 U.S.C. § 18a).

210. See, e.g., Greenbaum \& Meese, supra note 129; Spears, supra note 5.

211. See 15 U.S.C. § 18 a.

212. See 11 U.S.C. $§ 363$ (b) (2); 15 U.S.C. $§ 18$ a.

213. Prior to 1994 there was confusion with regard to the waiting periods to be applied.

214. See 15 U.S.C. $§ 18$ a. Parties not infrequently voluntarily agree to extend one or another of these periods if they believe they can convince the agencies not to sue to block the merger.

215. See id. When the Bankruptcy Code was amended in 1994 to adopt the $15+10$ dual waiting period structure, the usual waiting period was $30+20$, so the bankruptcy and cash tender offer waiting periods were exactly $1 / 2$ of the usual periods. When the usual period was amended to $30+30$, taking effect in 2001, the bankruptcy and cash tender offer periods did not change. See Janet Ridge, Interim 
The most likely explanation for the shorter waiting period in bankruptcy is the concern for wasting asset value while the firm is operating under the cloud of Chapter 11 bankruptcy protection. Rapid reorganizations are believed to preserve estate value. Courts and commentators frequently refer to the necessity of speed in bankruptcy proceedings. ${ }^{216}$ Congress too has recognized, without explanation, the value of speed in bankruptcy reorganizations. ${ }^{217}$ Arguments that time is of the essence are not frequently supported with empirical evidence. ${ }^{218}$ The policy of encouraging speed at all costs serves the interests of the constituents of the bankruptcy estate, who will realize any benefit from preserving asset value while bearing a de minimis share of the harm from an anticompetitive business combination. ${ }^{219}$

HSR Rules Published, Antitrust L. Update (Wilmer, Cutler \& Pickering, Wash. D.C.), Jan. 25, 2001, https://www.wilmerhale.com/uploadedFiles/WilmerHale_ Shared_Content/Files/Editorial/Publication/Interim\%20HSR\%20Rules.pdf [https://perma.cc/D2SD-ZFRY].

216. See, e.g., Ira L. Herman, Statutory Schizophrenia and the New Chapter 11, 2 Am. BANKr. INST. J. 30, 30 (2007) (discussing "second policy imperative" of Chapter 11 bankruptcy as being "the need for speed" (internal quotation marks omitted)); Jay Lawrence Westbrook, The Commission's Recommendations Concerning the Treatment of Bankruptcy Contracts, 5 Am. Bankr. Inst. L. Rev. 463, 474 n.84 (1997) (citing Nat'l Bankr. Rev. Comm'n, Bankruptcy: The Next Twenty Years, Final Report 451 (1997)); see also In re Lewis, 147 B.R. 37, 38 (Bankr. W.D. Mo. 1992) (“[I]t was the duty of the Bankruptcy Court to speed proceedings and to monitor reorganization cases very closely" in service of goal to preserve shareholder value (citing United Sav. Ass'n of Tex. v. Timbers of Inwood Forest Assoc., 484 U.S. 365 (1988))); Air Line Pilots Ass'n, Int'l v. Easter Air Lines, Inc. (In re Ionosphere Clubs, Inc.), 105 B.R. 765, 771 (Bankr. S.D.N.Y. 1989) (refusing to permit arbitration proceeding to continue during Eastern Air Lines bankruptcy, noting that "allowing the arbitration to proceed would usurp the bankruptcy court's critical role in the reorganization proceedings, affect special bankruptcy interests, and thwart the goal of judicial speed and economy which is particularly necessary for the rehabilitation of this Debtor"), vacated on other grounds, 922 F.2d 984 (2d Cir. 1990); In re Sw. Oil Co., 84 B.R. 448, 453 (Bankr. W.D. Tex. 1987) ("Speed is the thrust of the 1978 Reform Act, as it pertains to reorganization under Chapter 11.”).

217. See H.R. ReP. No. 95-595, at 222 (1977) (“[M]ore often than not, speed in the reorganization attempt is more important to success than the scope of the reorganization.”).

218. See Jacoby \& Janger, supra note 4 , at 862.

219. Speed may frustrate rather than advance estate value maximization goals. For example, asset values may be best realized after careful preparation and sale procedures. Cf. In re Nellis, 12 B.R. 770, 772 (Bankr. D. Conn. 1981) (citing legislative history to the Bankruptcy Code regarding the differences between a sale by a "careful and diligent businessman" " and a liquidation sale) (quoting H.R. Rep. No. 95-595, at 339). Professor Westbrook has noted, "[p]art of the essence of reorganization bankruptcy-heresy though it may be to say it-is delay, within reason." Westbrook, supra note 216 , at 474 . Delay serves the quintessentially bankruptcy goals of permitting the debtor "breathing room" to reorganize. Id. 


\section{Short Review Periods Undermine Merger Challenges and Present Forum- Shopping Concerns}

Short agency review periods for reportable business combination transactions under 363(b) might also be justified on the basis of a preference for those transactions' consummation, in spite of antitrust concerns. Waiting periods permit the antitrust enforcement agencies to reach judgments about the relative costs and benefits of a proposed transaction through discovery-like processes including issuing subpoenas for documents, interviewing third-party witnesses, taking depositions of party witnesses, and hiring and preparing economic and industry experts. ${ }^{220}$

At the end of the waiting periods, the agencies must sue to enjoin the transaction or risk its prompt consummation. Where consummation occurs, unwinding a merger or substantial asset sale can be difficult or impossible. Remedying transactions post-confirmation regularly is likened to "unscrambl[ing] the egg." 221 On the flip side of the coin, a transaction that is blocked-even preliminarily-frequently fails to proceed. ${ }^{222}$ The expectation of a permanent injunction after a preliminary injunction has issued is sufficiently great to cause deals to unwind.

Requiring agency counsel to litigate over a transaction with less than the sixty-day review period is likely to undermine their ability to successfully enjoin anticompetitive transactions. As one example, expert testimony may be difficult or impossible to prepare in the twenty-five days permitted by the foreshortened review periods for bankruptcy mergers or asset sales. Careful consideration of theories of antitrust liability is difficult to accomplish, even with full waiting periods, to say nothing of the abbreviated periods provided for 363(b) sales.

In contrast, the merging parties have advance knowledge of both their planned transaction and the likely agency response, so they are not prejudiced by the short preparation time. One example is SunGard Data Systems' purchase of Comdisco Inc. in a Section 363(b) sale conducted as part of Comdisco's bankruptcy proceedings. Counsel to SunGard published an article regarding the sale after the U.S. District Court denied the sought injunction. Counsel noted that, having anticipated the Antitrust Division's requests for documents and information, the merging parties were able to respond to those requests immediately on receiving them, limiting the Antitrust Division to the statutory twenty-five days. ${ }^{223}$ That strategy seems likely to have undermined the Division's ability to effectively litigate against the transaction, which involved a sophisticated and

220. See Merger Review Process, supra note 14.

221. See FTC v. Univ. Health Inc., 938 F.2d 1206, 1217 n.23 (11th Cir. 1991) (internal quotation marks omitted).

222. Consider, for example, the recent preliminary injunction against the proposed sale of US Foods to Sysco. The parties abandoned the transaction rather than continue litigating at the permanent injunction stage of proceedings.

223. Axinn, supra note 136. 
difficult to establish theory of the relevant antitrust market. ${ }^{224}$ Counsel's retrospective article on the SunGard/Comdisco business combination suggests that forum shopping by first filing bankruptcy may have been the parties' explicit intent.

\section{363(b) Transactions Undermine Antitrust Goals in Other Ways}

Nothing about Section 363(b) ensures that antitrust concerns relating to a business combination transaction pursued under that section are respected. Bankruptcy courts have broad authority to allow or to deny the proposed sale of assets. That authority is highlighted in Section 105(a) of the Bankruptcy Code, which permits courts to "issue any order, process, or judgment that is necessary or appropriate to carry out the provisions of this title."225 Bankruptcy courts cite the Section 105(a) power to supplement Section 363(b) when approving business combinations. ${ }^{226}$

Nothing in Section 363(b) or elsewhere in the Bankruptcy Code prescribes standards cabining the bankruptcy court's decision. Case law limits discretion to ensure business combinations serve the goals of maximizing estate value and increasing the likelihood of success in reorganization. ${ }^{227}$ Bankruptcy courts do not seek to accomplish other social policy goals when evaluating requests to sell assets or firms under Section $363(\mathrm{~b}) .228$

The Section 363(b) asset sale process does a poor job of accommodating antitrust concerns. Even if they had appropriate incentives to do so, bankruptcy courts do not enjoy discretion to give weight to the objections of antitrust enforcement agencies or private antitrust plaintiffs when reviewing mergers or asset sales conducted under Section 363(b) during the pendency of the bankruptcy proceeding.

224. One might argue that the existence of longer review periods outside of bankruptcy increase the likelihood that an agency forced to litigate on a foreshortened clock will be unsuccessful. Agency counsel may be accustomed to a pace of preparation that is inconsistent with operating under bankruptcy court supervision. Courts may be accustomed to receiving presentations of evidence that are much more robust than is possible on a shorter clock. It is possible that neither counsel nor courts are sufficiently flexible to adjust to the alternative procedures.

225. See 11 U.S.C. $\$ 105$ (a) (2012).

226. See, e.g., In re AMR Corp., No. 11-15463(SHL), 2013 WL 2643174, at *2, (Bankr. S.D.N.Y. June 10, 2013).

227. See Asarco, Inc. v. Elliot Mgmt. (In re ASARCO LLC), 650 F.3d 593, 601 (5th Cir. 2011) (stating sale should comport with an "articulated business justification for using, selling, or leasing the property outside the ordinary course of business" (internal quotation marks omitted)); Ginger Root Office Assocs., LLC v. Farmer (In re Advanced Packaging \& Prods. Co.), 426 B.R. 806, 816 (C.D. Cal. 2010) (applying abuse of discretion standard of review); see also Institutional Creditors of Cont'l Air Lines, Inc. v. Cont'l Air Lines, Inc. (In re Cont'l Air Lines, Inc.), 780 F.2d 1223, 1226 (5th Cir. 1986) (same); Comm. of Equity Sec. Holders v. Lionel Corp. (In re Lionel Corp.), 722 F.2d 1063, 1071 (2d Cir. 1983) (applying business judgment rule).

228. See Command Performance Operators, Inc. v. First Int'l Servs. Corp. (In re First Int'l Servs. Corp.), 25 B.R. 66, 70 (Bankr. D. Conn. 1982). 
A variety of more specific concerns with asset sales under Section 363(b) exist. There is no reporting process for mergers or asset sales that do not meet the HSR threshold, threatening the possibility that those sales occur without antitrust review. ${ }^{229}$ There is no express requirement that non-stakeholders in the bankruptcy proceeding may appear to challenge the merger or sale. ${ }^{230}$ Merger challenges that go to trial outside of bankruptcy may be tried to a jury, while claims tried before a bankruptcy court do not include a jury right. ${ }^{231}$

\section{Bankruptcy Courts Make Poor Antitrust Judges}

Bankruptcy judges are institutionally ill-suited to render decisions on merger matters, which represent one of the most complex and policyladen areas of antitrust review. First, bankruptcy judges can be expected to be unschooled in antitrust decision-making relative to generalist district court judges. Second, bankruptcy judges are trained to think in terms of protecting investor interests in firms in bankruptcy to the exclusion of non-investor interests, including consumers and society at large. Third, appellate review of bankruptcy court decisions is frequently less robust than appellate review of decisions by trial courts in other litigation settings. Finally, evaluation of bankruptcy judges, who are not life-tenured, turns on their success deciding bankruptcy issues.

These realities regarding the institutional competence of bankruptcy courts to hear antitrust matters explain the apparent, but unstated, ${ }^{232}$ reluctance of the antitrust enforcement agencies to bring merger challenges before bankruptcy courts. In cases discussed in the remainder of this Part, both the FTC and the Antitrust Division have endeavored, with differing degrees of success, to ensure their anti-merger arguments were heard by district courts rather than by bankruptcy courts.

229. This concern is not specific to bankruptcy proceedings, but it is possible that the circumstances of bankruptcy, including rapid reorganizations, may exacerbate the effect of non-reporting by undermining the ability of the agencies or would-be complainants to learn of and act on the proposed merger or sale.

230. As a practical matter, bankruptcy courts appear willing to hear challenges brought by the enforcement agencies.

231. This concern arises if private plaintiffs rather than federal agencies bring the merger challenge. Federal merger challenges either occur before the Federal Trade Commission or in district court; in the latter case a jury is highly unlikely.

232. Efforts to study agency decision-making in this regard have been unsuccessful due to agency assertions of privilege from Freedom of Information Act (FOIA) disclosure of documents or information reflecting decision-making processes. However, conversations with attorneys and managers with both enforcement agencies, as well as knowledgeable observers, support the conclusion of reluctance to proceed in the bankruptcy forum. 


\section{E. Representative Cases and Degrees of Antitrust Enforcement Success}

In Part III(A)-(D), this Article categorized business combination transactions pursued in the course of a bankruptcy proceeding. ${ }^{233}$ The first category involved competing bidders, where the bankruptcy reorganization goals (but not necessarily value maximization goals) could be achieved without the anticompetitive business combination transaction. The second, related category involved a business combination transaction that was unnecessary to accomplish a reorganization. Such a category could only be justified on the basis of value maximization. The third involved a business combination transaction without which the reorganization would have been impossible.

From 1991 to the present, an increasingly sophisticated approach to merger enforcement in the context of bankruptcy has developed. Lessons from the FTC's Financial News Network debacle informed the Antitrust Division's approach in Comdisco. The Antitrust Division's litigation failure in Comdisco improved its own approach to merger enforcement in the context of the AMR Corporation bankruptcy.

\section{In re Financial News Network}

One example of the conflict between antitrust law's merger policy goals and a bankruptcy asset sale proceeding is the litigation involving the Federal Trade Commission and state attorneys general over the sale of Financial News Network to General Electric, the parent company of competitor Consumer News and Business Channel. The proposed transaction was a merger to monopoly in the market for cable financial news reporting. The FTC's aborted effort to block the merger between General Electric (CNBC) and bankrupt firm Financial News Network represents an early and naïve attempt to block a bankruptcy business combination on the basis of antitrust concerns.

Westinghouse Corp. offered a competing bid for the Financial News Network assets. Had the bid succeeded, FNN would have continued to compete with CNBC, retaining a duopoly in the market. Every indication was that Westinghouse, a conglomerate that competed with CNBC-owner GE in many product lines, was a legitimate competing bidder for the FNN assets.

Because of the Westinghouse bid, even if FNN would have been unlikely to reorganize in bankruptcy, the FNN sale to GE could not be justified on the basis of the failing-firm defense. The bankruptcy court rejected the Westinghouse bid on the basis of bid procedures favoring GE. Bid procedures are established on the basis of value maximization goals and the rejection of the Westinghouse bid is evidence of favoring value maximization over the competitively preferable alternative.

233. See supra notes $167-232$ and accompanying text. 
The FTC appealed the bankruptcy court's determination that it had jurisdiction over the agency's antitrust challenge to the business combination with successful bidder GE. After the bankruptcy court's jurisdiction over the antitrust challenge was upheld, the agency dropped its challenge. ${ }^{234}$

\section{In re Comdisco}

Another example of this conflict is the Antitrust Division's challenge to the acquisition by competitor SunGard Data Systems of bankrupt Comdisco, Inc., a merger that created a duopoly in the market for electronic data storage services. ${ }^{235}$ SunGard/Comdisco involved a Section 363(b) business combination undertaken in the course of Comdisco's bankruptcy proceeding in Chicago. ${ }^{236}$ The Antitrust Division's litigation against SunGard's purchase of Comdisco ten years after Financial News Network showed lessons learned from the Financial News Network bankruptcy, but once again reflected the difficulties presented by the jurisdictional overlaps between bankruptcy and antitrust proceedings.

Hewlett Packard was a possible alternative bidder for the Comdisco assets. Because Hewlett Packard was not a competitor at the time, its bid would preserve three firms operating in the market. Like the GE-FNN transaction, a failing-firm defense would be unavailable to support the SunGard-Comdisco business combination.

The Justice Department opposed the business combination. It first sought to preclude the bankruptcy court's approving the 363(b) transaction by sending a letter to the bankruptcy court indicating its intent to challenge the transaction as a violation of the Clayton Act. The bankruptcy court returned the Justice Department's letter unopened. Bankruptcy proceedings were nonetheless stayed while the Justice Department

234. Information explaining the FTC's decision to drop the challenge to the business combination is not publicly available.

235. For another example, consider the American Airlines purchase of the assets of Trans-World Airlines Inc. in 2001. American's bid for TWA succeeded despite a competing bid by industry insiders who planned to maintain TWA as a free-standing competitor. See New Bidder for T.W.A. Emerges, N.Y. Times, Feb. 8, 2001, http://www.nytimes.com/2001/02/08/business/new-bidder-for-twa-emer ges.html [http://perma.cc/PL34-XR7D] (discussing bid for TWA assets by Jet Acquisitions Group, which intended to continue to operate TWA assets as free-standing airline).

236. Professor LoPucki lists the Comdisco bankruptcy as one of several that reflected that bankruptcy court's participation in the competition for major company bankruptcies in the early part of the prior decade. It seems likely the antitrust advantage made the bankruptcy forum-and in particular the Section 363(b) mechanism-more attractive than seeking to effect the business combination outside of bankruptcy or through a plan sale. See supra notes 125-37 and accompanying text. It would be an interesting inquiry whether the hope of easy confirmation of the proposed business combination enhanced the attractiveness of the Chicago forum. 
proceeded with a challenge to the proposed business combination in federal district court.

Antitrust counsel for the merging parties conducted its defense to the expected merger challenge in a manner that maximized the advantage from the short waiting periods for agency review of business combinations under 363(b). By preparing in advance and complying quickly with the anticipated government's second request, the parties to the business combination were able to limit Justice Department review of the proposed combination to the bare minimum waiting period provided for in Section 363(b) - approximately a month-before the government filed its complaint seeking an injunction. ${ }^{237}$

The apparent result was a hastily prepared Justice Department merger challenge in a complex economic sector. The challenge unsurprisingly failed on the basis of a problematic market definition. The SunGard/Comdisco business combination, which dramatically reduced competition in the market relative to the alternative combination with Hewlett Packard, succeeded because of procedures for 363(b) sales that favor hasty consummation of business combinations at the expense of careful antitrust review.

\section{In re AMR Corp.}

The US Airways/American Airlines business combination shows a second category of transaction that was unnecessary to realizing the benefits of keeping the bankrupt firm's assets operating in the market of concern. The bankruptcy court approved the business combination in June 2013, applying Section 363(b) as informed by the bankruptcy court's general equitable power. ${ }^{238}$ In the American Airlines bankruptcy and US Airways/American Airlines merger, the Antitrust Division's approach to merger review and enforcement in the context of a bankruptcy proceeding reflected lessons learned over two decades since Financial News Network.

The transaction reduced the number of major competitors in the market from five to four, leading to further consolidation in a market already characterized by a small number of major firms and well-understood to possess oligopoly characteristics. From the perspective of antitrust law, its consummation raises fundamental concerns. As the Justice Department claimed in its August 2013 complaint seeking to enjoin the transaction, industry consolidation and the elimination of maverick competitor US Airways threatened harm to consumers in the form of increased prices and decreased service on a large number of domestic city-pair routes. ${ }^{239}$

237. Internal agency deliberations are not publicly available, making it difficult to know the impact of the parties' defense strategy on Justice Department deliberations.

238. See In re AMR Corp., No. 11-15463(SHL), 2013 WL 2643174 (Bankr. S.D.N.Y. June 10, 2013) (applying 11 U.S.C. $\$ \S 363(\mathrm{~b}), 105(\mathrm{a})$ ).

239. On one hand, the CEO of the combined firm publicly predicted, "As the largest airline in the world, we should be the most profitable ...." See Susan Carey 
Theory suggests that the US Airways/American Airlines business combination, by conferring pricing power on the combined firm, should represent a high-value opportunity for the constituents of the bankruptcy estate. Stock market results post-merger suggest the theoretical expectation has borne out. Market observers noted extraordinary profit potential for equity investors in bankrupt AMR Corp., who, according to conventional bankruptcy wisdom, might have expected to lose their entire investment. ${ }^{240}$

\section{Why the Problem Remains}

Knowledgeable observers continue to question whether the merger enforcement in US Airways/American Airlines, which was conducted in parallel with the American Airlines bankruptcy proceeding, was as successful as it might have been if conducted outside of bankruptcy. Too, bankruptcy remains a notoriously localized practice, and the success of merger enforcement when the bankruptcy proceeding is before one particular bankruptcy court judge says little about a future merger matter in parallel with a bankruptcy proceeding taking place in a different jurisdiction. In particular, considering incentives to forum shop and broad discretion facing bankruptcy counsel with regard to where to file, a filing made in a bankruptcy court with judges less inclined to be deferential to antitrust concerns might be a strategic ploy. ${ }^{241}$

Based on evidence from the US Airways/American Airlines merger, enforcers' experience can mitigate the challenges of investigating and challenging a merger in parallel with a bankruptcy proceeding. Theoretical potential remains for suboptimal antitrust enforcement when bankruptcy courts are uncooperative and merging parties seek maximal advantage from the foreshortened waiting periods. Necessity remains for a theoretically sound and pragmatic solution to the conflicts.

\& Jack Nicas, American Airlines, US Airways Complete Merger, WALl ST. J., Dec. 10, 2013, http://online.wsj.com/news/articles/SB10001424052702303560204579247 953849152692 [http://perma.cc/R334-BTNF] (quoting Doug Parker, CEO, US Airways) (internal quotation marks omitted). On the other hand, a white paper publicized by the American Antitrust Institute analyzed efficiency claims in airline mergers and concluded efficiencies have rarely been realized. See Diana L. Moss, Am. Antitrust Inst., Delivering the Benefits? Efficiencies and Airline Mergers 3-10 (2013), http://www.antitrustinstitute.org/sites/default/files/AAI_USAirAA_Efficiencies.pdf [http://perma.cc/LWY4-3N9N]. The conflicting understandings of the profitability of a business combination transaction like that of US Airways and American Airlines can be explained by the expectation that the combined firm will enjoy substantial pricing power.

240. 'It 'was just about the best bankruptcy ever,' said Starke, a managing director at CRT Capital Group in Stamford, Conn. 'It's insane how well it turned out." 'See Bill Rochelle, Shares of Old AMR Stock Are Gaining Value, Analyst Says, Fort Worth Star-Telegram (Dec. 18, 2013), http://www.star-telegram.com/ 2013/12/18/5429015/shares-of-old-amr-stock-worth.html [http://perma.cc/ 3JTK-7JHL] (quoting Kevin Stark, industry analyst). 42.

241. On discretion and forum shopping generally, see LoPUCKI, supra note 


\section{Optimal Reconciliation}

Part III identified deep and enduring conflicts between antitrust merger control and bankruptcy business reorganizations. Differences in goals between business bankruptcies and competition policy suggest that conflicts will arise whenever there is a substantial bankruptcy in a concentrated industry. Those have been frequent in recent decades, and the representative cases in the prior sub-part show that conflicts do arise. This Part is the first effort to identify which policy should prevail in seeking the optimal legal and regulatory approach to mergers in declining industries.

\section{A. A Clash Between Groups of Diffuse Claimants}

Both bankruptcy and antitrust can be understood as seeking to mitigate disparities in bargaining power that emerge when constituents are unable to protect their own interests in bilateral bargaining with the firm. Upstream investor interests include employees, communities, creditors, and equity investors (suppliers of labor, geography, capital, and entrepreneurship) and are diffuse relative to the bankrupt firm. That relative diffusion undermines those investors' bargaining power vis-à-vis the firm: a large percentage of the individual investors lack the ability to dictate terms or to demand timely compensation. The opposite problem arises when the bankrupt firm's relationship with consumers is considered. Like investors, consumers are too diffuse to protect their individual interests when bargaining with the bankrupt firm.

It is less obvious that the interests of the diffuse investors are opposed to the interests of the diffuse consumers. The Chapter 11 reorganization, including the asset sale or merger conducted as part of it, can be seen as sharing economic value from the market in which the firm operates between upstream claimants (investors) and downstream claimants (consumers). The consumers benefit if the asset or firm is diminished, improving their bargaining position in relation to it. The investors benefit if the asset or firm is enhanced, increasing the value to be distributed among them. If the economy is static, the situation is zero-sum: a benefit realized by either class of claimants is offset by a loss suffered by the other class of claimants.

The zero-sum nature of this tug-of-war between consumers and investors operating in the market in which the assets or firm operate(s) explains why the conflict between bankruptcy law's estate value maximization goal and antitrust law's consumer protection goal is irreconcilable. This refined understanding also enables steps toward an optimal balance between the competing policy goals.

\section{B. Diffuse Claimants Lacking Ex Ante Bargaining Opportunity Must Prevail}

In the tradition of law-and-economics that dominates both antitrust and business bankruptcy scholarship and policy-making, this Article asserts that economic efficiency is a guiding principle in analyzing both antitrust 
law and bankruptcy law. ${ }^{242}$ Bargaining disparity produces market failures leading to inefficient resource allocations. Regulatory intervention can be appropriate to correct for such market failure. ${ }^{243}$

Evaluating which set of claimants is more diffuse and therefore in greater need of legal intervention to mitigate the market failure caused by bargaining disparity helps to resolve the conflict between and antitrust and bankruptcy. In the ordinary circumstance, the more diffuse set of claimants will be consumers. Investors frequently band together in the form of labor unions and pooled capital investment schemes such as mutual funds. Creditors are themselves sophisticated and capital-intensive enterprises.

In contrast, consumers typically bargain individually, competing against one another for scarce opportunities to contract with suppliers in the industry. Economic theories of collective action demonstrate consumers are unlikely to interact collectively to protect their collective best interests. The antitrust enterprise exists to protect those interests, which the bargaining process frequently undermines.

Stakeholders in bankruptcy proceedings, including creditors, equity investors, and employees of the bankrupt firm, have the further advantage of an opportunity to bargain ex ante to protect their interests in the context of bankruptcy. Stakeholders have the ability to assess the risk of contracting with the debtor firm before its filing and adjust contract terms on the basis of those risks. For example, creditors may take security interests, gaining the protections of security including first right to recovery from the debtor's assets. ${ }^{244}$ Other creditors adjust the terms of their credit relationship, including interest charges or repayment schedules, based on risk assessments. Equity holders adjust the prices they pay for ownership of the debtor's equity shares to reflect concerns for loss in bankruptcy. Finally, even employees, the least well-protected of the stakeholders, have some ability to recover wages due ${ }^{245}$ and to bargain for payment terms in light of expectations regarding the firm's failure.

In contrast, in the ordinary course, consumers do not form advance contract relationships that give them stakeholder status in bankruptcy proceedings. Exceptions to this general reality include long-term contracts that place a consumer in the position of a creditor ${ }^{246}$ and down payments

242. See, e.g., Broad. Music, Inc. v. Colum. Broad. Sys., Inc., 441 U.S. 1, 19-20 (1979) (noting antitrust serves economic efficiency); Thomas H. Jackson \& Robert E. Scott, On the Nature of Bankruptcy: An Essay on Bankruptcy Sharing and the Creditors' Bargain, 75 VA. L. Rev. 155, 155-56 (1989); Richard A. Posner, The Rule of Reason and the Economic Approach: Reflections on the Sylvania Decision, 45 U. CHI. L. Rev. 1, 12-13 (1977).

243. See, e.g., Richard A. Posner, Economic Analysis of the Law 343 (3d ed. 1986); Daniel D. Barnhizer, Inequality of Bargaining Power, 76 U. Colo. L. Rev. 139, 214 (2005).

244. See 11 U.S.C. $\S \S 506(a)-(b), 725$ (2012).

245. See id. $\$ 507(\mathrm{a})(4)$.

246. See id. $\$ 365$. 
on consumer goods that have the same effect. ${ }^{247}$ In the ordinary course, consumers are pure non-stakeholders who rely on the preservation of efficiency in the industry but have little to no ability to enforce that goal through their own action.

\section{Ties Should Break in Favor of Merger Enforcement Policy}

The totality of considerations favors antitrust law's merger policy goals over bankruptcy's value maximization goals. Even where equally diffuse, the localized constituents of the bankruptcy estate are better positioned than the consumers to protect their interests. Shareholders and creditors both are in contract relationships with the bankrupt firm. Those contracts are subject to negotiation. The interests of the shareholder and creditor counter-parties can be protected through negotiation.

For these reasons, we are willing, outside of bankruptcy, to prefer consumer interests to shareholder and creditor interests. We will subject firms and, derivatively, their owners and creditors to financial penalties for anticompetitive conduct, including illegal mergers. The only difference between the non-bankruptcy and bankruptcy circumstances is the timing. Analogizing to the principle of Butner v. United States, ${ }^{248}$ equity holders and creditors should not be better off in bankruptcy than they were out of bankruptcy.

\section{Proposals for Reform}

Part IV explained the optimal reconciliation of the conflict between antitrust merger review and bankruptcy business reorganizations as one that favors the goals of antitrust. Reform is necessary to bring about that reconciliation. In this part, the Article offers paths to reform to correct for a status quo that suffers from a tendency toward false negatives in the application of antitrust policy to business combinations conducted under the supervision of a bankruptcy court. The possible approaches include amendments to the Bankruptcy Code as well as changes to interpretations of the Code in its current form.

\section{A. Reorganization Plans Better Protect Antitrust Review of Bankruptcy Business Combinations}

Moving to greater use of plan sales versus Section 363(b) sales for bankruptcy business combinations is the most direct and obvious route to mitigate the tension between the policies of bankruptcy law and those of antitrust. The feasibility test for plan approval under Section 1129 promises the best check on the use of the bankruptcy forum to effect business combinations that violate the Clayton Act. Merger review procedures

247. See id. $\$ 507(\mathrm{a})(7)$.

248. 440 U.S. 48 (1979), superseded in statute, Bankruptcy Reform Act of 1994, Pub. L. No. 103-394, 108 Stat. 4106. 
under that section allow for full review, conducted under the normal $30+30$ day waiting period mandated in the HSR Act. ${ }^{249}$

The incentives facing bankruptcy courts at the plan confirmation stage are different than the incentives at the time of an out-of-the-ordinary-course-of-business asset sale or merger conducted under Section 363(b). Instead of seeking to maximize asset value to enable a reorganization to occur, the plan confirmation process seeks to ensure that a business structure is in place that will permit a firm to continue to be successful after confirmation. ${ }^{250}$ The legality of a business combination conducted as part of a plan of reorganization is inextricably linked to the feasibility of the reorganization. ${ }^{251}$ Stakeholders in the bankruptcy proceeding have incentive and opportunity to bring problematic proposals for business combinations to the attention of the antitrust enforcement agencies, mitigating problems of non-reportable transactions evading antitrust review. ${ }^{252}$

Unlike in the context of Section 363(b) sales, which one writer argues are part of a race-to-the-bottom competition among bankruptcy courts, courts do not stand to benefit by confirming plans that immediately fail due to antitrust challenges to business combinations. ${ }^{253}$ The reputational penalty to a court associated with plan failure caused by a court's enjoining the transaction would be greater than in the context of failures that occur over a longer time horizon. Such a failure-by-injunction would be immediate and readily traceable to a failing in the plan confirmation process. ${ }^{254}$

Legislative change might give effect to what is generally agreed to be the real thrust of Section 363(b) - sales of assets, not entire businesseswith the effect of shifting business combinations to the plan confirmation stage of proceedings. Such an amendment might include as part of paragraph (b) (1): "Any sale of all or substantially all of the property of the estate may be conducted under this section only if the court determines after notice and a hearing that confirmation of a plan under this Chapter is highly unlikely to succeed." 255 The hypothetical amendment preserves the 363(b) sale option for emergency cases but narrows the current "business rationale" requirement, through which most such sales are justified. The likely success of the hypothetical amendment, even if enacted, is sub-

249. See supra notes $215-17$ and accompanying text.

250. See supra notes 80-83 and accompanying text.

251. See supra notes $84-89$ and accompanying text.

252. See supra notes 74-79 and accompanying text.

253. But cf. LoPucki, supra note 42, at 137-40, 167-80 (arguing that Section 363(b) business combinations are indication of corrupted reorganization proceedings).

254. But cf. id. at 97-122 (recognizing plan failure as regular feature of modern large public company reorganizations but fact of high failure rates are not ascribed to bankruptcy courts' failures).

255. The language draws on the "plan sale" paragraph of the Bankruptcy Code, Section 1123(b) (4). 
ject to question: two authors argue that the "melting ice cube" argument for 363(b) sales has been accepted as a matter of course, suggesting that courts might simply begin to conclude that plans can never succeed. ${ }^{256}$

\section{B. Withdrawing the Reference for Antitrust Merger Challenges}

One resolution to the concern that expertise and institutional incentives favor value maximization over antitrust goals would be to challenge the results of Section 363(b) asset sales in district court, relying on the bankruptcy court to hold off on its decision approving the sale until the district court decides the antitrust claim. Withdrawal of the reference with regard to antitrust review of assets sales would be an elegant mechanism resolving the tension between the bankruptcy court's estate-value-maximization goals and competition policy concerns raised by the asset sale.

The Judiciary Code provides:

The district court shall, on timely motion of a party, so withdraw a proceeding if the court determines that resolution of the proceeding requires consideration of both title 11 and other laws of the United States regulating organizations or activities affecting interstate commerce. ${ }^{257}$

In operation, the mandatory withdrawal approach would involve a challenger to a bankruptcy asset sale appearing in bankruptcy court, raising that challenge, and moving the district court to withdraw the reference to decide the antitrust issue. ${ }^{258}$ Bringing this approach into the mainstream would involve either common-law interpretations of Section 157 (d) that require withdrawal when a Clayton Act challenge is brought to a bankruptcy business combination or changes to the bankruptcy reference procedure imposed by district court rule.

\section{Mandatory Withdrawal in Operation}

Petitioning the district court to "withdraw the reference" is a means to move proceedings from the bankruptcy court-where they may be heard only by reference from an Article III judge-to a federal trial court. Such a move has two clear benefits. First, federal district courts are generalist courts, frequently with some experience in antitrust matters, while bank-

256. See generally Jacoby \& Janger, supra note 4.

257. 28 U.S.C. $\$ 157$ (d) (2012).

258. As a formal matter, withdrawal of the reference could occur in one of two ways. First, proceedings that are considered "non-core" are required to be reviewed de novo by the referring district court on the timely objection of any party. See id. $\$ 157$ (c)(1). A determination that an antitrust challenge to a bankruptcy asset sale is non-core would change the fact-finder to a tribunal less likely to be predisposed to allow the transaction. Second, even when a proceeding is core, an interested party may seek to have the district court exercise its discretion to withdraw the reference "for cause shown." Id. $\$ 157(\mathrm{~d})$. Withdrawal occurs by motion made to the district court. FED. R. BANKr. P. 5011. 
ruptcy courts are specialized tribunals whose judicial work is focused entirely on federal bankruptcy law. At least one commentator has noted that bankruptcy judges may be myopic with regard to non-bankruptcy matters. ${ }^{259}$ Second, bankruptcy proceedings are directed entirely to maximizing estate value and not to the broader economic impacts of the proceedings as those economic impacts affect entities that are not constituents of the estate.

Under the broadest interpretation of Section $157(\mathrm{~d})$, the mere necessity of resolving an antitrust challenge would be a basis for mandatory withdrawal. This approach reads the word "consideration" to mean what it says-if the court must "consider" antitrust law, withdrawal is required. This approach has been pejoratively called the "literal theory." 260 Most courts have refused to read the word "consideration" so broadly for fear of "creat[ing] an 'escape hatch" "that "would eviscerate much of the work of [the] bankruptcy courts."261 The prevailing interpretation of 157 (d) reads "consideration" to mean "material and substantial consideration,"262 suggesting both that the consideration of antitrust (or other federal) law must be material to the outcome and that the amount of consideration is significant.

Several courts have held the standard to be met in the presence of antitrust claims. In Lifemark Hospitals v. Liljeberg Enterprises, claims that contracts involving the debtor were illegal tying arrangements presented a basis for mandatory withdrawal when the claims did not present per se violations of the antitrust laws. Instead, the court must decide, "among other things, definition of the relevant product and geographic market area, and determinations of whether competition was unreasonably restrained by a tying or exclusive dealing agreement, whether a particular hospital lease constituted a tying product, and whether debtor's conduct constituted an unfair trade practice." 263 This was "more than routine application of established [antitrust] law."264 In In re National Gypsum Co., patent claims with antitrust counterclaims "necessarily entailed material and substantial consideration of non-Code federal law,"265 and in Burger King Corp. v. B-K of Kansas, a creditor's trademark claims and the debtor's

259. See Cole \& Zywicki, supra note 7 , at 511.

260. See Hvide Marine Towing, Inc. v. Kimbrell (In re Hvide Marine Inc.), 248 B.R. 841, 843 (M.D. Fla. 2000).

261. See Am. Body Armor \& Equip., Inc. v. Clark (In re Am. Body Armor \& Equip., Inc.), 155 B.R. 588, 590 (M.D. Fla. 1993) (quoting In re Adelphi Inst., Inc. v. Terranova, 112 B.R. 534, 536 (S.D.N.Y. 1990); In re Johns-Manville Corp., 63 B.R. 600, 603 (S.D.N.Y. 1986)) (internal quotation marks omitted).

262. See 1 Collier on Bankruptcy 3-57 (17th Ed. 2015) (citing cases).

263. See Lifemark Hosps. Inc. v. Liljeberg Enters., Inc. (In re Liljeberg Enters., Inc.), 161 B.R. 21, 25 (E.D. La. 1993). The court cited Jefferson Parish Hosp. Dist. No. 2 v. Hyde, 466 U.S. 2, 11-17 (1984), for the standard for tying claims.

264. See Lifemark Hosps., 161 B.R. at 25.

265. See U.S. Gypsum Co. v. Nat'l Gypsum Co. (In re Nat'l Gypsym Co.), 145 B.R. 539, 542 (N.D. Tex. 1992). 
antitrust and RICO counterclaims met the standard. ${ }^{266}$ And in Michigan Milk Producers Ass'n v. Hunter, antitrust counterclaims presented a basis for mandatory withdrawal because they required "substantial and material consideration of federal antitrust claim[s]."267 The counterclaim in question "alleged that a supply agreement entered into between [creditor] and [debtor] was in violation of the Sherman Antitrust Act, 15 U.S.C. $§ 1 . " 268$

\section{Narrowing Interpretations of $157(d)$}

Although several examples exist of antitrust issues that satisfy the prevailing Section 157 (d) standard for mandatory withdrawal, there are limits to relying on this approach. First, none of the successful arguments arise in the merger context. Second, courts paying close heed to narrowing interpretations of $157(\mathrm{~d})$ have often reached the opposite conclusion on antitrust claims. Third, the most extreme narrowing interpretation of Section $157(\mathrm{~d})$, advanced by a small minority of courts and a leading bankruptcy treatise, would almost certainly prove insurmountable in the context of any merger challenge to a bankruptcy business combination.

\section{a. Interpretation, Not Application}

One commonly accepted narrowing interpretation of the mandatory withdrawal provision speaks to the degree of "interpretation" of the nonbankruptcy that is required. The Seventh Circuit in In re Vicars Insurance Agency distinguished between "mere application" and "interpretation," outlining three approaches from the "least restrictive end of the spectrum" to the "most restrictive interpretations" of $157(\mathrm{~d}) .{ }^{269}$ The In re Vicars Insurance Agency court preferred the middle approach: "mere presence of a non-title 11 issue, even if that issue is outcome determinative," is not sufficient to invoke mandatory withdrawal (although permissive withdrawal remains available), but neither is it essential that "non-title 11 issues 'dominate[ ]' bankruptcy issues." 270 Instead, "consideration of both title 11 and other laws of the United States" involves a court's "undertak[ing] analysis of significant open and unresolved issues regarding 1986).

266. See Burger King Corp. v. B-K of Kan., Inc., 64 B.R. 728, 731 (D. Kan. $1985)$.

267. See Mich. Milk Producers Ass'n v. Hunter, 46 B.R. 214, 216 (N.D. Ohio

268. Id. at 215.

269. See In re Vicars Ins. Agency, Inc., 96 F.3d 949, 953 (7th Cir. 1996) (citing City of N.Y. v. Exxon Corp., 932 F.2d 1020, 1026 (2d Cir. 1991); United States v. Johns-Manville Corp. (In re Johns-Manville Corp.), 63 B.R. 600, 603 (S.D.N.Y. 1986)).

270. See id. at 953 (citing Contemporary Lithographers, Inc. v. Hibbert (In re Contemporary Lithographers), 127 B.R. 122, 127 (M.D.N.C. 1991) (providing permissive approach); In re Lenard, 124 B.R. 101, 102 (D. Colo. 1991) (providing restrictive approach)). 
the non-title 11 law" as distinct from "mere application of existing law to new facts." 271

Courts have held that the elements of mandatory withdrawal are not met when antitrust claims other than merger issues are raised in bankruptcy, although only rarely in cases in which the antitrust issues were squarely presented and fully articulated. In Hawaiian Airlines, Inc. v. Mesa Air Group, Inc., the antitrust issues were raised in counterclaims, where the original claims were within the bankruptcy court's jurisdiction as core proceedings. ${ }^{272}$ Noting both that "the antitrust and other federal law issues in this case appear to be straightforward and not matters of first impression" and that "Mesa has not identified those portions of the antitrust laws which it contends will require substantial and material consideration," the Hawaiian Airlines court concluded mandatory withdrawal was not required. ${ }^{273}$

There is only one example of a mandatory withdrawal motion being addressed in the context of a merger challenge to a bankruptcy business combination. Both the Commonwealth of Pennsylvania and the State of Illinois, continuing their litigation to enforce the Sherman Act after the Federal Trade Commission abandoned its challenge to the CNBC/FNN transaction, moved the district court to withdraw the reference. ${ }^{274}$ Noting circuit precedent that suggested withdrawal might be mandatory if the matter involved "significant interpretation of CERCLA," the district court

271. See id. at 954; see also United States v. Delfasco, Inc., 409 B.R. 704, 707 (D. Del. 2009) (distinguishing "'substantial and material' consideration of federal law" (withdrawal mandatory) from "straightforward application of a federal law" (not mandatory)).

272. See Hawaiian Airlines, Inc. v. Mesa Air Grp., Inc., 355 B.R. 214, 218-23 (D. Haw. 2006).

273. See id. at 223. Hawaiian Airlines can thus be explained as a failure to fulfill a burden of proof. See also Hvide Marine Towing, Inc. v. Kimbrell (In re Hvide Marine Inc.), 248 B.R. 841, 843 (M.D. Fla. 2000) (holding no mandatory withdrawal for oblique reference to "unlawful monopolistic activities in violation of the Sherman Antitrust Act" and other federal law). Other cases refusing mandatory withdrawal in the presence of antitrust issues do not involve meaningful assertions of antitrust issues to be decided. The district court in In re Mathson Industries, Inc. held that a claim of collusion affecting the outcome of a Section 363(b) asset sale, while couched as antitrust issue (bid-rigging), was actually a claim about the application of Bankruptcy Code Section 363(n), which imports the bid-rigging standard into the bankruptcy code as a reason to set aside a bankruptcy sale. 408 B.R. 888, 891 (E.D. Mich. 2009). It was irrelevant that "the existence of a Sherman Act violation would help Plaintiff prove her claim ....” Id. In an analogous case, assertion of state-law antitrust claims that would be decided by reference to analogous federal law did not provide a basis for mandatory withdrawal, because the federal law was not binding. Kiep v. Turner, 80 B.R. 521, 524 (D. Haw. 1987).

274. See Dow Jones/Grp. W Television Co. v. Nat'l Broad. Co., 127 B.R. 3, 4 \& n.1 (S.D.N.Y. 1991). 
held that a merger challenge was a "mere application of established antitrust principles to new facts." 275

Such a narrow interpretation of Section 157 (d) undermines a policy of mandatory withdrawal whenever antitrust merger issues are presented in the context of a bankruptcy business combination. Enacted in 1950, the Clayton Act has existed in substantially its current form for more than six decades. Since 1968, increasingly sophisticated versions of the Guidelines have been considered, promulgated, and generally accepted. Most mergers brought to the antitrust enforcement agencies for review are permitted to proceed without challenge and even minimal investigation using the early termination procedure. The core challenge in merger litigation is the application of complex facts to well-established legal principles. A party seeking to have a matter removed to the district court would be hard-pressed to argue that the merger challenge meets the In re Vicars Insurance Agency standard for mandatory withdrawal.

\section{b. "Only One Law"}

One pair of commentators opposed mandatory withdrawal for questions of merger enforcement arising in reorganization cases under a more extreme narrowing interpretation of the mandatory withdrawal standard. ${ }^{276}$ These opponents of mandatory withdrawal base their arguments on interpretations of Judiciary Code Section 157(d), requiring withdrawal "on timely motion of any party ... if the court determines that resolution of the proceeding requires consideration of both title 11 and other laws of the United States." 277 They argue that the only law being interpreted is the Clayton Act because Section 363(b) is not subject to different interpretations. A small minority of lower courts follow this "only one law" approach. ${ }^{278}$

That interpretation of Section 157 (d) is wrong-headed. Every bankruptcy court decision approving a business combination (whether as part of a plan or under 363(b)) necessarily interprets the Bankruptcy Code. ${ }^{279}$

275. Id. at 4-5 (citing City of N.Y. v. Exxon Corp., 932 F.2d 1020 (2d Cir. 1991)) (noting withdrawal may be mandatory if interpretation of CERCLA is required).

276. See Greenbaum \& Meese, supra note 129, at 37; see also Collier, supra note 262, at 3-62 (noting "probably the correct way [to read Section $157(\mathrm{~d})$ ] is that the district court is not required to withdraw" proceeding only presenting an antitrust issue).

277. 28 U.S.C. $\$ 157(d)$ (2012).

278. See, e.g., Brizendine v. Montgomery Ward \& Co., 143 B.R. 877, 878-89 (N.D. Ill. 1992); Monterey Mushrooms, Inc. v. Carolina Produce Distribs., Inc. (In re Carolina Produce Distribs., Inc.), 110 B.R. 207, 209 (W.D.N.C. 1990); Sibarium v. NCNB Tex. Nat'l Bank, 107 B.R. 108, 111 (N.D. Tex. 1989); In re System Freight, No. 90-4908, 1991 WL 33150, at*2 (D.N.J. Mar. 6, 1991); Block v. Anthony Tammaro, Inc. (In re Anthony Tammaro, Inc.), 56 B.R. 999, 1006 (D.N.J. 1986).

279. Cf. Burger King Corp. v. B-K of Kan., Inc., 64 B.R. 728, 731 (D. Kan. 1986) (stating resolution of relief requires application of bankruptcy law, but not requiring any showing of interpretive difficulties surrounding bankruptcy issues). 
If antitrust questions are also present, then "both title 11 and other laws of the United States" language of Section $157(\mathrm{~d})$ is satisfied. ${ }^{280}$ The "only one law" argument also ignores the justification for making and withdrawing the reference. Because the reference to bankruptcy courts is justified by their unique expertise in bankruptcy matters, the reference should be withdrawn when matters outside that unique expertise are presented for decision. ${ }^{281}$ Those non-bankruptcy matters are better handled by generalist district court judges who possess generalized experience and the security of life tenure. ${ }^{282}$

\section{Overcoming the Narrowing Interpretations}

The distinction between successful arguments for mandatory withdrawal and those that are unsuccessful turns primarily on movants' ability to demonstrate a need for "interpreting, not applying" or "material and substantial consideration of" antitrust law. Most unsuccessful motions raising antitrust issues appear to fail based on their oblique references to antitrust claims or counter-claims, without a meaningful demonstration of the complexity of those claims. In contrast, successful motions show the interpretive challenges inherent in deciding the antitrust issue. For example, the assertion of a tying challenge in Lifemark Hospitals succeeded in producing withdrawal to the district court when the movant described the difficult issues of market definition, reasonableness of the restraint, and the existence of a tying product. ${ }^{283}$ In contrast, the unsuccessful motion

280. See Nancy C. Dreher et al., Bankruptcy Reference Manual \$ 2.11 (Norton, 5th ed. 2014) (noting most courts hold that interpretation be of nonbankruptcy scheme). A leading treatise advances the most extreme possible interpretation of Section 157 (d). Collier on Bankruptcy hews literally to the statutory text to suggest both bankruptcy and non-bankruptcy issues must be present for mandatory withdrawal, in keeping with the small minority of cases and commentators like Greenbaum and Meese. See Collier, supra note 262, at 3-55 to 3-57. The same treatise then advances the view, in deviation from the statutory text that involvement in the non-bankruptcy law must extend beyond mere "consideration" (the statutory term) to "substantial and material consideration." See id. at 3-56 to 3-57 \& n.19 (citing cases). That approach cannot be justified by any statutory interpretive methodology and can only be explained by a full-throated preference to the narrowest possible reading of the mandatory withdrawal provision.

281. See Franklin Sav. Ass'n v. Office of Thrift Supervision, 150 B.R. 976, 980 (D. Kan. 1993) (stating that minority approach would incongruously leave matters involving only non-bankruptcy issues in bankruptcy court, while matters involving partly bankruptcy issues would be withdrawn).

282. See Am. Freight Sys., Inc. v. Interstate Commerce Comm'n (In re Am. Freight Sys., Inc.), 150 B.R. 790, 794 (D. Kan. 1993); Sullivan v. Hiser (In re St. Mary Hosp.), 115 B.R. 495, 497 (E.D. Pa. 1990); United States v. Johns-Manville Corp. (In re Johns-Manville Corp.), 63 B.R. 600, 602 (S.D.N.Y. 1986); see also CoLLIER, supra note 262, at 3-62 (stating district courts are better equipped than bankruptcy courts to determine non-bankruptcy federal issues). "Possibly Congress was wary of the possibility that a bankruptcy judge would favor the Code provision that conflicted with a provision contained in another federal statute and wanted district judges to have the last word on where the case would be tried." Id.

283. See supra notes 263-64 and accompanying text. 
in Hawaiian Airlines involved antitrust counterclaims but no demonstration of what "portions of the antitrust laws" were implicated.284

A full description of the process for deciding a complex merger issue should satisfy the need to tailor the withdrawal motion to that in Hawaiian Airlines. To an extent even greater than tying claims, full consideration of a merger challenge involves market definition, calculation of market shares and changes in market shares, consideration of the competitive effects of the business combination, consideration of possible efficiencies that might emerge and a determination whether those efficiencies are specific to the proposed business combination, and consideration of the failing-firm defense. The merger challenge ultimately turns on the net effect on competition from the business combination-whether the competitive effects are overborne by, or overbear, the asserted efficiencies and the failing-firm defense. A well-drawn motion describing the process, including ample reference to the Guidelines, with a preliminary demonstration that the proposed business combination presents facial concerns for unresolved competitive effects, easily meets the standard.

To the extent that courts hew to the excessively narrow interpretations of Section 157(d), either (1) requiring difficult interpretations of both the Bankruptcy Code and the antitrust laws or (2) understanding merger review to be mere application of facts to settled law, those approaches will require change, whether by common law, court rule, or legislation. The common law approach is the most promising. The interpretation of Section 157 (d) followed by the majority of courts should, in the presence of well-made motions, require antitrust challenges to bankruptcy business combinations to be decided by district courts.

\section{Dismissals of Bankruptcy Petitions for Bad Faith}

Bankruptcy courts have the power, on request and after holding a hearing, to dismiss Chapter 11 bankruptcy petitions "for cause" under Bankruptcy Code Section 1112. ${ }^{285}$ "Cause" includes abuse of the bankruptcy process, which has been found in cases in which a financially healthy debtor sought bankruptcy to avoid antitrust liability. In SGL Carbon Corp., the bankruptcy court concluded a desire to avoid antitrust liability in a suit alleging that price fixing was not a "valid reorganizational purpose" and upheld the bankruptcy court's dismissal of the Chapter 11 petition. ${ }^{286}$ Bad faith dismissals operate to screen out bankruptcy petitions that are not consistent with the policies underlying bankruptcy law.

An analogous screen exists at the plan confirmation stage, where bankruptcy courts are charged by Code Section 1129(a) to confirm only those plans "proposed in good faith." 287 Good faith is a poorly defined

284. See supra notes $272-73$ and accompanying text.

285. See 11 U.S.C. $\$ 1112$ (b) (1) (2012).

286. 200 F.3d 154 (3d Cir. 1999).

287. See 11 U.S.C. $\$ 1129(\mathrm{a})(3)$. 
phrase "generally interpreted to mean that there exists 'a reasonable likelihood that the plan will achieve a result consistent with the objectives and purposes of the Bankruptcy Code.'"288 Good faith for purposes of confirmation exists where "there is a reasonable likelihood of reorganizing the debtor" even if the plan is not the best possible approach to satisfying creditor claims. ${ }^{289}$ A more stringent phrasing of the good faith requirement for plan confirmation requires "an arguable relation [ ] between the chapter 11 plan and the reorganization-related purposes that the chapter was designed to serve." 290

The uses of "good faith" in Sections 1112 (as a judicial gloss on "cause") and 1129, while fundamentally disparate as a procedural matter, are unsurprisingly intertwined. ${ }^{291}$ Some version of a good faith requirement has existed in bankruptcy legislation at least since the 1898 Bankruptcy Act. ${ }^{292}$ Interpretations of historical good faith requirements for plan confirmation operated to prevent the debtor from using bankruptcy "to accomplish an inequitous or unfair result, or to obtain a result contrary to the spirit of the statute . . ."293

Existing interpretations of "cause" and "good faith" requirements in Chapter 11 give little support to an argument that pursuing bankruptcy to facilitate a business combination either is a bad faith basis for filing or represents a bad faith plan proposal. The Bankruptcy Code has not been interpreted and applied to accommodate non-stakeholder interests or external regulatory concerns like antitrust law. Common law or legislative change would be required to accomplish this result.

Legislative change might involve one or both of two Code amendments. First, the definition of "cause" in Code Section 1112(b) (4) might be amended to include "violation of controlling federal or state regulatory

288. In re Madison Hotel Assocs., 749 F.2d 410, 425 (7th Cir. 1984) (quoting In re Nite Lite Inns, 17 B.R. 367, 370 (Bankr. S.D. Cal. 1982)) (internal quotations omitted), superseded in statute, Bankruptcy Amendments and Federal Judgeship Act, Pub. L. No. 98-353, § 508, 98 Stat. 353 (1984).

289. Nite Lite Inns, 17 B.R. at 370-71. In other words, good faith arguments should not provide a basis for advancing one proposed plan over another.

290. Connell v. Coastal Cable T.V., Inc. (In re Coastal Cable T.V., Inc.), 709 F.2d 762, 764 (1st Cir. 1983).

291. See In re Victory Const. Co., 9 B.R. 549, 551 (Bankr. C.D. Cal. 1981) ("As the cases disclose, however, judicial analysis of the meaning, scope, and dimension of 'good faith' in rehabilitation or reorganization cases has not differentiated between the 'good faith' required to confirm a plan of arrangement, and the 'good faith' required at the outset as a condition of the right to file and maintain the proceeding."), order vacated, 37 B.R. 222 (B.A.P. 9th Cir. 1984).

292. See id. at 551-56 (tracing history of good faith requirements in bankruptcy legislation).

293. See id. at 555-56 (interpreting Bankruptcy Act of 1898, Section 12) (footnote omitted). The court discussed other interpretations that spoke to concerns for hiding or wasting estate assets. Id. 
requirements." 294 Second, the good faith requirement for confirmation in Section 1129(a)(3) might be amended to include "or in violation of controlling federal or state regulatory requirements." 295 The first is the most promising change to achieve the goals of ensuring the bankruptcy process is not abused to achieve business combinations that the antitrust laws would forbid. Plan sales present substantially lesser concerns for undermining the antitrust merger review process. ${ }^{296}$ Section 1112 is the appropriate section to control abusive business combinations under Section $363(\mathrm{~b})$.

Amending Section 1112 to mitigate the use of bankruptcy filings solely to achieve anticompetitive business combinations is both an underinclusive and an overinclusive remedy. "Cause" would still only be found if the business combination was planned in advance of the filing and the filing was made solely to facilitate the combination in violation of the Clayton Act. ${ }^{297}$ Business combinations that violate the Clayton Act that are planned after the petition was filed (or even planned in advance but do not represent the cause for the filing) should not create cause for dismissing the petition. The amendment would be over inclusive because it threatens a cottage industry built on motions claiming cause for a violation of myriad federal or state regulatory schemes. Bankruptcy courts would necessarily become adept at processing such arguments quickly, risking the ultimate effect that any such motion is functionally ignored.

\section{Agency Review of Less-Anticompetitive Alternatives}

A different approach to accomplishing the goal of stronger antitrust review in bankruptcy is to amend the Hart-Scott-Rodino Act to provide an entirely new structure for agency investigation of bankruptcy business combinations. Under this proposed approach, the antitrust enforcement agencies would be given opportunity to investigate for up to thirty days after a bankruptcy-court ordered business combination to proceed in district court seeking injunctive relief. The injunction would be granted if the enforcement agency could demonstrate a less anticompetitive option for disposing of the assets that is not unreasonably unfair to the constituents of the bankruptcy estate.

Under this approach, the Department of Justice would have succeeded in preliminarily blocking the SunGard/Comdisco business combination, because would-be new entrant Hewlett Packard was willing and

294. Such an amendment would be consistent with the exception to the automatic stay for "enforce[ment of a] governmental unit's . . police and regulatory power.” 11 U.S.C. $\$ 362$ (b) (4).

295. See id. $\S 1129$ (a) (3). This addition might fairly be considered redundant to the existing language "not by any means forbidden by law," although the existing language has not been held to encompass concerns for external regulation.

296. See supra notes 249-56 and accompanying text.

297. Examples include American Airlines/TWA and SunGard/Comdisco. 
able to purchase the Comdisco assets. ${ }^{298}$ Likewise, the presence of alternate bidder Westinghouse in the Financial News Network asset sale would allow the FTC to achieve an injunction against the approved transaction on the basis of a less competitive alternative.

The effect of such a thirty-day post-sale-order agency review would be to create a shadow over bankruptcy business combinations that creates incentives for parties to the business combinations, as well as bankruptcy courts, to avoid anticompetitive business combinations. The effect would be similar to the current process of feasibility testing prior to plan confirmation: bankruptcy courts would gain little from approving a Section 363 (b) sale if the danger existed of a short-term injunction against the sale. Another effect of such an amendment would be to reduce the incentives to file bankruptcy in order to facilitate a business combination that is threatened with antitrust challenge.

\section{Conclusion}

Business combinations present antitrust concerns under the Clayton Act if the transaction would "tend to create a monopoly." In the ordinary course such merger review proceeds according to well-defined and wellunderstood procedural rules and substantive standards, whether in district court or in the FTC administrative process. Generalist federal judges and the FTC can be assumed to be competent to enforce the Clayton Act with an appreciation of the competitive dynamics that underlie federal merger policy. Ordinary course merger review recognizes the competitive realities failing firms and declining industries present. In the common circumstance of business combinations' occurring in bankruptcy, those well-defined procedures and substantive standards can be subordinated to a host of bankruptcy-specific rules and policies.

Commentators have noted that business combinations are so common as to have become a driving purpose for business bankruptcies. The Bankruptcy Code contains a parallel scheme for conducting business combinations after the bankruptcy filing. Two primary mechanisms operate to allow bankruptcy court review and approval of asset sales that meet the requirements of bankruptcy law. First and most common is the out-of-theordinary-course-of-business sale of assets under Code Section 363(b). Second is the more procedurally involved sale of assets conducted as part of the plan of reorganization under Chapter 11.

This Article demonstrates that identical competitive issues arise in the ordinary course and when the selling firm is in bankruptcy. But bankruptcy presents unique procedural challenges and countervailing substantive considerations. Procedures for review of asset sales in bankruptcy limit the opportunities for the antitrust enforcement agencies to conduct a careful analysis of the competitive consequences of the transaction.

298. See supra notes 235-37 and accompanying text. 
Bankruptcy courts may aim to maximize the value of the estate and to protect the interests of stake-holders. Those aims are in tension with antitrust goals of economic efficiency in service of consumer interests.

Those differences alter the antitrust analysis when merger review is conducted in the context of bankruptcy. The conflict creates a likelihood that anticompetitive mergers arising in the course of bankruptcy proceedings either (1) go unchallenged or (2) survive over challenges that might have been successful outside of the bankruptcy context. The conflict between bankruptcy and antitrust will necessarily bring about under enforcement of the antitrust anti-merger prohibition relative to the optimum.

This Article addresses the optimal resolution of the conflict. Both bankruptcy and antitrust pursue end goals of protecting constituents who lack the bargaining power to protect themselves through contracting. The conflict is fundamentally a conflict between diffuse stakeholders in the bankrupt firm and diffuse consumers of the bankrupt firm's output.

Tensions, where they arise, should be resolved in favor of consumers for three reasons. First, creditors have the ex ante ability to bargain for protection in a way that consumers do not. Second, merger policy outside of bankruptcy is a mature scheme that has developed through common law and legislative change since 1890; has been reduced to well understood principles in case-law, agency decisions, and enforcement guidelines; and, as enforced for the past several decades, is a minimalist scheme that favors allowing mergers to proceed if the merger promises efficiencies. Third, merger policy outside of bankruptcy incorporates efficiency considerations related to failing companies under the failing-firm defense, protecting the policies of bankruptcy to the extent they are not inconsistent with antitrust goals.

Reform is appropriate to resolve this conflict and to move the level of antitrust review of bankruptcy asset sales toward the optimum. This Article closes by proposing several reform possibilities, a combination of which may be required to bring about the optimal balance between the goals of bankruptcy and those of antitrust. 